\title{
Molecular Characterization, Expression Analysis of Carotenoid, Xanthophyll, Apocarotenoid Pathway Genes, and Carotenoid and Xanthophyll Accumulation in Chelidonium majus L.
}

\author{
Ramaraj Sathasivam ${ }^{1,+}{ }^{\oplus}$, Hyeon Ji Yeo ${ }^{1,+}$, Chang Ha Park ${ }^{1}$, Minsol Choi ${ }^{1}$, Haejin Kwon ${ }^{1}$, Ji Eun Sim ${ }^{2}$, \\ Sang Un Park 1,3,*D and Jae Kwang Kim $2, *$ (D) \\ 1 Department of Crop Science, Chungnam National University, 99 Daehak-ro, Yuseong-gu, \\ Daejeon 34134, Korea; ramarajbiotech@gmail.com (R.S.); gusw17627@gmail.com (H.J.Y.); \\ parkch804@gmail.com (C.H.P.); 201802785@o.cnu.ac.kr (M.C.); kwonhaejin42@o.cnu.ac.kr (H.K.) \\ 2 Division of Life Sciences, College of Life Sciences and Bioengineering, Incheon National University, Yeonsu-gu, \\ Incheon 22012, Korea; ajaj7433@inu.ac.kr \\ 3 Department of Smart Agriculture Systems, Chungnam National University, 99 Daehak-ro, Yuseong-gu, \\ Daejeon 34134, Korea \\ * Correspondence: supark@cnu.ac.kr (S.U.P.); kjkpj@inu.ac.kr (J.K.K.); \\ Tel.: +82-42-821-5730 (S.U.P.); +82-32-835-8241 (J.K.K.); Fax: +82-42-822-2631 (S.U.P.); +82-32-835-0763 (J.K.K.) \\ + Ramaraj Sathasivam and Hyeon Ji Yeo contributed equally to this work.
}

Citation: Sathasivam, R.; Yeo, H.J.; Park, C.H.; Choi, M.; Kwon, H.; Sim, J.E.; Park, S.U.; Kim, J.K. Molecular Characterization, Expression Analysis of Carotenoid, Xanthophyll, Apocarotenoid Pathway Genes, and Carotenoid and Xanthophyll Accumulation in Chelidonium majus L. Plants 2021, 10, 1753. https:// cdoi.org/10.3390/plants10081753

Academic Editors: Suvi T. Häkkinen and Kirsi-Marja Oksman-Caldentey

Received: 30 July 2021

Accepted: 20 August 2021

Published: 23 August 2021

Publisher's Note: MDPI stays neutral with regard to jurisdictional claims in published maps and institutional affiliations.

Copyright: (c) 2021 by the authors. Licensee MDPI, Basel, Switzerland. This article is an open access article distributed under the terms and conditions of the Creative Commons Attribution (CC BY) license (https:/ / creativecommons.org/licenses/by/ $4.0 /)$.
Abstract: Chelidonium majus L. is a perennial herbaceous plant that has various medicinal properties. However, the genomic information about its carotenoid biosynthesis pathway (CBP), xanthophyll biosynthesis pathway (XBP), and apocarotenoid biosynthesis pathway (ABP) genes were limited. Thus, the $\mathrm{CBP}, \mathrm{XBP}$, and $\mathrm{ABP}$ genes of $C$. majus were identified and analyzed. Among the 15 carotenoid pathway genes identified, 11 full and 4 partial open reading frames were determined. Phylogenetic analysis of these gene sequences showed higher similarity with higher plants. Through 3D structural analysis and multiple alignments, several distinct conserved motifs were identified, including dinucleotide binding motif, carotene binding motif, and aspartate or glutamate residues. Quantitative RT-PCR showed that CBP, XBP, and ABP genes were expressed in a tissue-specific manner; the highest expression levels were achieved in flowers, followed by those in leaves, roots, and stems. The HPLC analysis of the different organs showed the presence of eight different carotenoids. The highest total carotenoid content was found in leaves, followed by that in flowers, stems, and roots. This study provides information on the molecular mechanisms involved in $\mathrm{CBP}, \mathrm{XBP}$, and ABP genes, which might help optimize the carotenoid production in C. majus. The results could also be a basis of further studies on the molecular genetics and functional analysis of $\mathrm{CBP}, \mathrm{XBP}$, and ABP genes.

Keywords: Chelidonium majus; carotenoid pathway genes; xanthophyll pathway genes; apocarotenoid pathway genes; gene expression; carotenoid; xanthophyll

\section{Introduction}

Chelidonium majus belongs to the Papaveraceae family, and it is widely found worldwide, including Asia, Europe, North America, and Northern Africa [1]. The aerial parts of this plant consist of isoquinoline alkaloids (berberine, chelerythrine, chelidonine, coptisine, sangui-narine, and stylopine), whereas herbs of C. majus consist of carotenoids, flavonoids, organic acids, and proteins [2-7]. The extract of C. majus has various antioxidant properties (elimination of reactive oxygen species (ROS), and protection from oxidative stress), with a wide range of medicinal properties such as analgesic, anti-inflammatory, antimicrobial, anti-spasmodic, antitumor, antiviral, choleretic, and hepatoprotective properties [1,2,5,8-12]. It has also been used for the treatment of asthma, cancer, chronic bronchitis, eczema, gas- 
trointestinal diseases, liver disorder, oral infection, pain and nervous disorders, ringworm, and ulcer $[5,9,13]$.

To date, many natural carotenoids were identified from medicinal plants. It is important to screen, identify, and analyze various types of carotenoids because of their pharmacological benefits [3]. Most studies have only focused on $\beta$-carotene; however, recently, other carotenoids also play a vital role in human diets, which increases their attention [14]. Carotenoids are the most important natural pigments that play a significant role in scavenging reactive oxygen species (ROS) and in protecting plant cells from photooxidative damage [15]. It has a wide range of health benefits such as immunomodulatory, anticancer, antibacterial, antiaging, antidiabetic, anti-inflammatory, and neuroprotective effects [16-21]. In addition, carotenoids might also help to enhance the immune system [22].

Recently, several reviews have been published regarding the gene responsible for the regulation of the carotenoid biosynthesis pathway $(\mathrm{CBP})$, xanthophylls biosynthesis pathway $(\mathrm{XBP})$, and apocarotenoid biosynthesis pathway (ABP) genes in plants $[15,23]$ (Figure 1). Among these, the foremost is CBP, the genes involved in this pathway have been identified and characterized, such as Phytoene synthase (PSY) in bread wheat, citrus (Citrus unshiu Marc., Citrus sinensis Osbeck, Citrus limon Burm.f.), Hong Kong kumquat, Ixeris dentate, melon, Scutellaria baicalensis, summer squash, and sunflower [24-32]; Phytoene desaturase (PDS) in common Andrographis herb, citrus (Citrus unshiu Marc., Citrus sinensis Osbeck, Citrus limon Burm.f.), I. dentate, S. baicalensis, and wolfberry [26,29,31,33,34]; $\zeta$-carotene isomerase (Z-ISO) in Arabidopsis and Osmanthus fragrans [35,36]; $\zeta$-carotene desaturase (ZDS) in carrot, Chinese cabbage, citrus (Citrus unshiu Marc., Citrus sinensis Osbeck, Citrus limon Burm.f.), Ficus carica, S. baicalensis, and wolfberry [26,31,33,37-40]; carotenoid isomerase (CrtISO) in cabbage, citrus (Citrus sinensis L Osbeck; cv. "Pera"), and wolfberry [33,41,42]; lycopene $\beta$-cyclase (LCYB) in Arabidopsis, citrus (Citrus unshiu Marc., Citrus sinensis Osbeck, Citrus limon Burm.f.), I. dentate, maize, papaya, persimmon, strawberry, sweet range, and wheat [26,29,43-50]; lycopene e-cyclase (LCYE) in Arabidopsis, citrus (Citrus unshiu Marc., Citrus sinensis Osbeck, Citrus limon Burm.f.), and strawberry [26,43,50]. The second is the $\mathrm{XBP}$, these pathway genes have been identified and characterized in plants such as $\beta$-ring carotene hydroxylase (CHXB) in citrus (Citrus unshiu Marc., Citrus sinensis Osbeck, Citrus limon Burm.f.), I. dentate, S. baicalensis, and strawberry [26,29,31,50]; e-ring carotene hydroxylase (CHXE) in I. dentate [29]; zeaxanthin epoxidase (ZEP) in citrus (Citrus unshiu Marc., Citrus sinensis Osbeck, Citrus limon Burm.f.), I. dentate, and S. baicalensis [26,29,31]; violaxanthin de-epoxidase (VDE) in Cucumis sativus, Phyllostachys edulis [51,52]; capsanthincapsorubin synthase (CCS) in Lilium lancifolium [53]. In another branch, the apocarotenoids were synthesized and the enzyme responsible for ABP genes have been identified and characterized in plants such as CCD in apple, chrysanthemum, citrus (Citrus sinensis L. Osbeck, Citrus clementina, C. clementina $\times$ Citrus reticulata), Crocus ancyrensis, osmanthus, rose, and S. baicalensis [54-58]; 9-cis-epoxycarotenoid dioxygenase (NCED) in Arabidopsis, and S. baicalensis [31,59]; aldehyde oxidase $(A O)$ in Zea mays [60].

Recently, a transcriptomic analysis of $C$. majus elaiosomes and seeds was carried out, together with the expression analysis of genes related to the fatty acid biosynthetic pathway [61]. In another study, a transcriptomic analysis of C. majus roots and leaves was conducted to analyze the expression profile of genes involved in benzylisoquinoline alkaloid biosynthetic pathway [62]. Khodabande et al. [9] analyzed the antioxidant activity, total protein, and soluble sugar content of C. majus leaf extracts during different growth stages. However, there are no published reports regarding the characterization and gene expression of CBP, XBP, and ABP genes (CmPSY, CmPDS, CmZDS, CmCrtISO, CmLCYB, CmLCYE, CmCHXB, CmCHXE, CmZEP, CmCCD, and CmNCED) and carotenoid accumulation in different organs (flowers, stems, roots, and leaves) of C. majus. Therefore, we analyzed the gene expression responses of $\mathrm{CBP}, \mathrm{XBP}$, and $\mathrm{ABP}$ genes in the different organs of C. majus using quantitative reverse-transcription polymerase chain reaction (qRT-PCR). Eight carotenoid compounds in the different organs of $C$. majus were also quantified using 
HPLC. The results can increase our understanding of CBP, XBP, and ABP genes and allow us to explore the strategies that could improve the anticarcinogenic properties of $C$. majus.

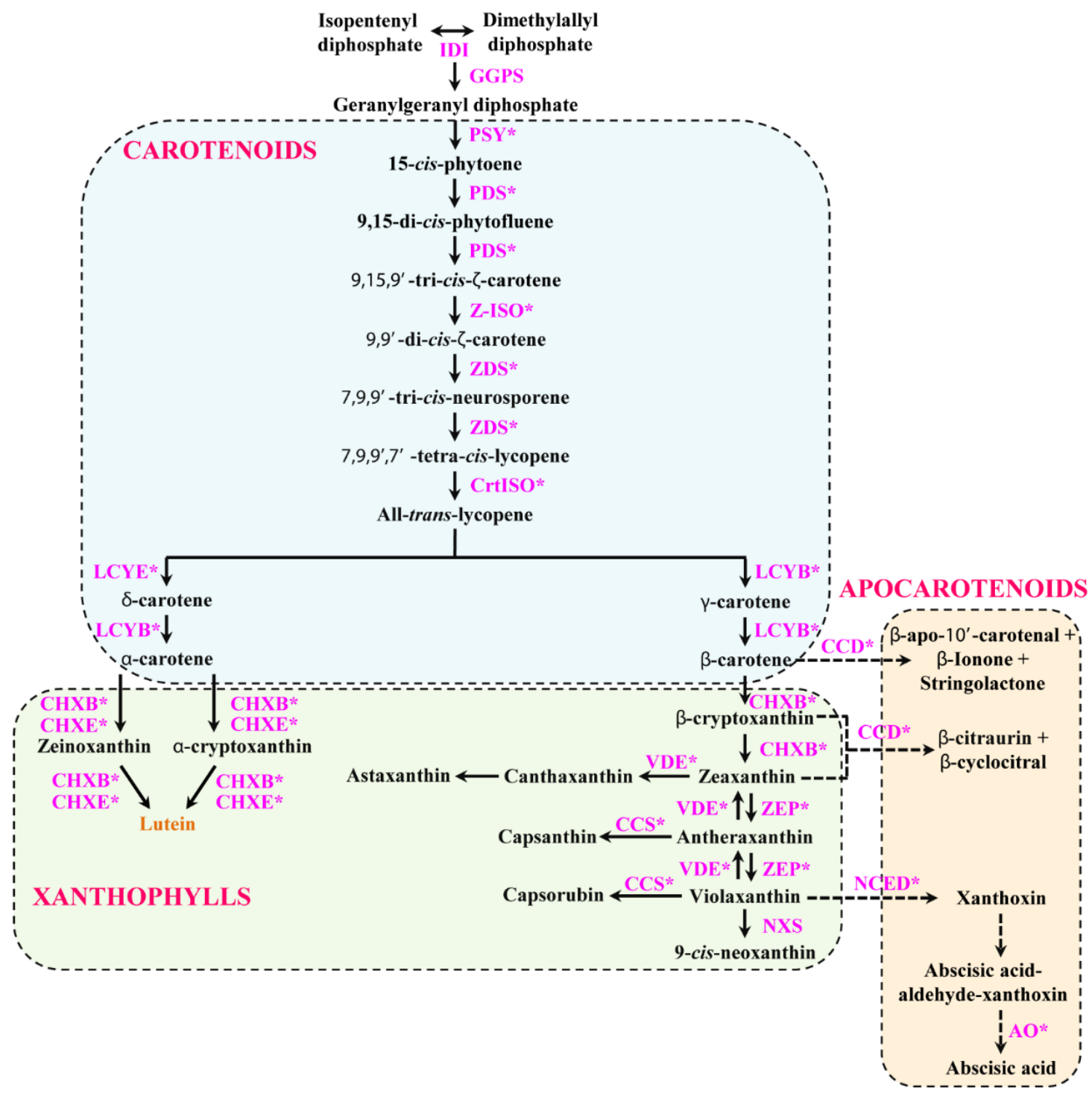

Figure 1. Proposed CBP, XBP, and ABP in Chelidonium majus. Enzymes are shown in pink. Asterisk denotes the gene used for identification, characterization, and gene expression studies. Solid black arrows represent biosynthesis and dotted black arrows represent the degradation of carotenoids.

\section{Results and Discussion}

\subsection{Identification, Protein Nomenclature, and Sequence Analysis of $C B P, X B P$, and ABP Genes}

From the transcriptomic data, the CBP, XBP, and ABP genes of C. majus were identified. The identified genes were used as queries to search using the BLASTN program from the NCBI database. The BLASTN results showed that all identified genes had a high similarity with their corresponding sequences in higher plants. Then, the identified sequences were subjected to NCBI's open reading frame (ORF) finder program to recognize whether the CBP gene has full ORFs. The genes with maximum nucleotide lengths were taken and subjected to structural and functional analysis. In addition, the genes that do not have full ORFs were also taken for structural and functional studies. A total of $15 \mathrm{CBP}, \mathrm{XBP}$, and ABP genes were identified; among these 11 full ORFs (CmPSY, CmPDS, CmZDS, CmCrtISO, CmLCYB, CmLCYE, CmCHXB, CmZEP, CmVDE, CmCCD, and CmAO) were determined, whereas $C m Z-I S O, C m C H X E, C m C C S$, and $C m N C E D$ possess partial ORFs (Table 1 and Figure S1). The predicted MWs and the estimated isoelectric points of the CBP, 
XBP, and ABP genes are shown in Table 1. The predicted MW was reported in other plant species, such as Brassica napus [63], I. dentate [29], Lycium chinenses [33], Nasturtium officinale (unpublished data), and S. baicalensis [31,57]. Among the identified CBP, XBP, and ABP genes, none of these genes have a transmembrane region. Similar results were obtained in higher plants, such as Musa acuminata [64], Brassica napus [65], N. officinale (unpublished data), Triticum aestivum [24], and green algae Tetraselmis suecica [21], which do not possess any transmembrane regions in their CBP genes.

Table 1. Molecular characterization of CBP genes in C. majus.

\begin{tabular}{cccccccc}
\hline $\begin{array}{c}\text { Gene } \\
\text { Names }\end{array}$ & $\begin{array}{c}\text { NCBI } \\
\text { Accession No. }\end{array}$ & $\begin{array}{c}\text { ORF } \\
(\mathbf{b p )}\end{array}$ & $\begin{array}{c}\text { Length } \\
(\mathbf{a a})\end{array}$ & $\begin{array}{c}\text { ORF } \\
\text { Type }\end{array}$ & $\begin{array}{c}\text { MW } \\
\text { (Kda) }\end{array}$ & pI & $\begin{array}{c}\text { Signal } \\
\text { Peptide }\end{array}$ \\
\hline CmPSY & MW307341 & 912 & 303 & Full & 36.36 & 9.56 & No \\
CmPDS & MW307330 & 1752 & 583 & Full & 69.96 & 6.81 & No \\
$C m Z-I S O$ & MW307331 & 734 & 244 & Partial & 29.28 & 6.71 & No \\
$C m Z D S$ & MW307344 & 1797 & 598 & Full & 71.76 & 7.89 & No \\
$C m C r t I S O$ & MW307336 & 1812 & 603 & Full & 72.36 & 8.79 & No \\
$C m L C Y B$ & MW307338 & 1518 & 505 & Full & 60.60 & 7.64 & No \\
$C m L C Y E$ & MW307339 & 1605 & 534 & Full & 64.08 & 6.49 & No \\
$C m C H X B$ & MW307333 & 948 & 317 & Full & 38.04 & 8.75 & No \\
$C m C H X E$ & MW307335 & 881 & 293 & Partial & 35.16 & 9.12 & No \\
$C m Z E P$ & MW307343 & 1998 & 665 & Full & 79.80 & 6.59 & No \\
$C m V D E$ & MW307342 & 1464 & 487 & Full & 58.44 & 5.13 & No \\
$C m C C S$ & MW307334 & 389 & 129 & Partial & 15.48 & 10.22 & No \\
$C m C C D$ & MW307337 & 1836 & 611 & Full & 73.32 & 6.23 & No \\
$C m N C E D$ & MW307340 & 549 & 183 & Partial & 21.96 & 10.40 & No \\
$C m A O$ & MW307332 & 4125 & 1374 & Full & 164.88 & 6.34 & No \\
\hline
\end{tabular}

Signal IP analyses showed that $\mathrm{CmCrtISO}$ had the maximum original shearing site (C score) values, followed by CmPSY, CmZDS, CmLCYE, CmVDE, CmCHXE, CmLCYB, CmZISO, CmCHXB, CmCCS, CmZEP, CmPDS, CmAO, CmNCED, and CmCCD, whereas CmZDS had the highest maximum synthesized shearing site ( $\mathrm{Y}$ score) values, followed by $\mathrm{CmCr}$ tISO, CmPSY, CmCHXE, CmCCS, CmLCYE, CmCHXB, CmCCD, CmLCYB, CmPDS, CmVDE, CmZ-ISO, CmZEP, CmAO, and CmNCED. CmZDS also had the maximum signal peptide (S score) values, followed by CmCCS, CmCHXE, CmCrtISO, CmPSY, CmLCYE, CmZ-ISO, CmCHXB, CmCCD, CmPDS, CmLCYB, CmVDE, CmZEP, CmNCED, and CmAO (Table 2).

Table 2. Percentage identity (\%) analysis of amino acid sequences, comparing between C. majus $\mathrm{CBP}$, XBP, and $\mathrm{ABP}$ genes and other $\mathrm{CBP}, \mathrm{XBP}$, and ABP amino acid sequences. Accession numbers of the sequences are provided in Figure S2 and Table S3.

\begin{tabular}{|c|c|c|c|c|c|c|c|c|c|c|c|c|c|c|c|}
\hline Species Name & PSY & PDS & Z-ISO & ZDS & CrtISO & $L C Y B$ & $L C Y E$ & CHXB & CHXE & $Z E P$ & $V D E$ & CCS & $C C D$ & NCED & $A O$ \\
\hline $\begin{array}{l}\text { Higher plants } \\
\text { C. majus } \\
\text { A. aestivalis }\end{array}$ & 100 & 100 & 100 & 100 & 100 & 100 & 100 & $\begin{array}{c}100 \\
7246\end{array}$ & 100 & 100 & 100 & 100 & 100 & 100 & 100 \\
\hline $\begin{array}{l}\text { C. sinensis } \\
\text { M. cordata }\end{array}$ & 89.77 & 82.30 & & & & 85.32 & 77.50 & & & & & & & & 71.55 \\
\hline $\begin{array}{l}\text { P. somniferum } \\
\text { Chlorophyta }\end{array}$ & & & 70.26 & 78.00 & 81.40 & & & & 81.60 & 82.56 & 76.39 & 70.65 & 79.53 & 68.05 & \\
\hline $\begin{array}{l}\text { C. primus } \\
\text { C. reinhardtii }\end{array}$ & & 63.60 & 55.63 & 56.36 & 55.93 & 51.23 & 41.49 & 44.96 & 48.95 & 49.08 & 40.41 & & 30.13 & & 30.72 \\
\hline $\begin{array}{l}\text { M. pusilla } \\
\text { O. tauri } \\
\text { Bacteria }\end{array}$ & 38.70 & & & & & & & & & & & & & $27.78 \%$ & \\
\hline Calothrix sp. & & & & & & & & & & & & & 36.36 & & \\
\hline D. bacterium & & & & & & 35.66 & & 44.03 & & & & & & & 32.86 \\
\hline $\begin{array}{l}\text { Geitlerinema sp. } \\
\text { O. cyanobacterium } \\
\text { R. bacterium }\end{array}$ & 35.00 & 66.03 & & 61.73 & 59.92 & & 35.82 & & & & & & & & \\
\hline $\begin{array}{l}\text { Spirulina sp. } \\
\text { Dinoflagellates }\end{array}$ & & & & & & & & & & & & & & 46.00 & \\
\hline $\begin{array}{l}\text { S. microadriaticum } \\
\text { Heterokonts }\end{array}$ & & 40.50 & & & 25.27 & & & & & 33.20 & 35.62 & & 25.44 & & 27.39 \\
\hline E. siliculosus & 2724 & & 2906 & 49.65 & 28.23 & 35.78 & & & & 32.15 & 40.44 & & 23.63 & & 3100 \\
\hline & & 59.75 & & & & & & 33.16 & & & & & & & \\
\hline
\end{tabular}


The homology analysis using CDD showed that the CBP, XBP, and ABP sequences had high similarity with other higher plant species, including the amino acids position 21-278 for CmPSY, 38-583 for CmPDS, 157-244 for CmZ-ISO, 1-581 for CmZDS, 41-580 for CmCrtISO, 61-503 for CmLCYB, 4-534 for CmLCYE, 1-314 for CmCHXB, 61-293 for CmCHXE, 1-647 for CmZEP, 83-484 for CmVDE, 85-129 for CmCCS, 46-609 for CmCCD, 66-183 for CmNCED, and 12-1371 for CmAO. The homology analysis of the CBP, XBP, and ABP genes of Dunaliella salina by CCD search showed a high homology with other chlorophyta and higher plants $[64,66,67]$. These results showed that the CBP, XBP, and $\mathrm{ABP}$ genes of $C$. majus are highly conserved compared with the genes of higher plants and green algae.

\subsection{Phylogenetic and Homology Analysis}

The phylogenetic tree between $C$. majus and other $\mathrm{CBP}, \mathrm{XBP}$, and ABP genes was constructed using a neighbor-joining method. The results showed that the CBP, XBP, and $A B P$ protein sequences of $C$. majus were grouped with other higher plants, whereas chlorophyte, bacteria, dinoflagellates, and heterokonts were grouped in a separate cluster (Figure S2). Several studies have reported that the phylogenetic analysis of CBP, XBP, and $\mathrm{ABP}$ genes in plants showed a close relationship with other higher plants, whereas other species formed separate clades [35,40,52,57]. Similarly, the identity matrix results showed that all CBP, XBP, and ABP genes shared sequence identities with the amino acid sequences of other higher plants, such as Adonis aestivalis, Camellia sinensis, Macleaya cordata, and Papaver somniferum. In addition, other species showed less sequence identity when compared with C. majus' CBP, XBP, and ABP amino acid sequences (Table 2). Similar results were obtained in S. baicalensis and I. dentate, where their CBP, XBP, and ABP amino acid sequences showed high similarity with higher plant species $[29,57,59]$. These results clearly showed that the CBP, XBP, and ABP genes of higher plants are highly conserved, which may share higher sequence identities with higher plants.

\subsection{Multiple Alignments and Tertiary Structure Analysis of $C B P, X B P$, and $A B P$ Genes}

Multiple alignments and predicted tertiary structures of $C$. majus $\mathrm{CBP}, \mathrm{XBP}$, and $\mathrm{ABP}$ proteins showed highly conserved domains as that of the higher plants $[29,50-52,54]$ and microalgae [66,68-70] (Figure S3 and Figures 2-4). Although there were few base changes in amino acid sequences, the protein function mainly depends on its tertiary structure and stability [71]. The tertiary structures of C. majus' CBP, XBP, and ABP protein sequences showed similar conformations of $\alpha$ and $\beta$ secondary structural elements and substratebinding pockets as that of $A$. thaliana, N. officinale, C. reinhardtii, and D. salina (data are not shown). However, there were little structural differences observed in the variable loop regions of the $\mathrm{CBP}, \mathrm{XBP}$, and $\mathrm{ABP}$ protein models, which might be due to their relatively low sequence identities [72]. These results agreed with the results of percent identities and multiple alignments in this study (Table 2 and Figure S3).

The predicted tertiary structure of C. majus' $\mathrm{CBP}, \mathrm{XBP}$, and $\mathrm{ABP}$ genes consist of a central hydrophobic substrate-binding pocket, which was created by the folding of $\alpha$-helices and $\beta$-sheet strand; the binding pocket was almost buried within the core of $\alpha$-helices. In addition, other domains including the carotene-binding domain (CBD), aspartate-rich domain (ARD), and dinucleotide-binding domain (DBD), were located near the cavity, which might be important for enzyme activity [66]. In detail, the key CBP pathway enzyme CMPSY consists of a conserved trans-isoprenyl diphosphate synthase domain and ARD in its amino acid sequence (Figure 2 and Figure S3). Similar conserved domains were present in the amino acid sequences of higher plants, such as S. baicalensis and $I$. dentate $[29,31]$. The second most important gene in this pathway is CmPDS, which consists of both DBD and CBD in its sequence, whereas CmZDS consists of similar identical features as that of $C m P D S$, which possesses a CBD and DBD at the C-terminal region and $\mathrm{N}$-terminal region, respectively. This result was similar to a previous study which showed that the PDS and ZDS amino acid sequence of higher plants (I. dentate, Carica papaya, 
and S. baicalensis) and marine green algae (D. salina) have these domains $[29,31,70,73]$. Both CmLCYB and CmLCYE possess a DBD in their structure (Figure 2 and Figure S3). This domain is present in all lycopene cyclases, which help in binding flavin adenine dinucleotides (FAD). In addition, a plant $\beta$-conserved region was also present in plant-type cyclases (CrtL) but not in bacterial CrtYm, and this $\beta$-conserved region might play a specific role in an interaction between the cyclases and components related to membrane-bound enzymes [74]. Moreover, another three conserved regions (cyclase motif 1, 2, and charged regions), were also found in lycopene cyclases, which are involved in substrate binding and catalysis [43]. These conserved domains were also present in higher plants (Arabidopsis and Capsicum annuum) and green algae (Haematococcus pluvialis) [43,74,75].
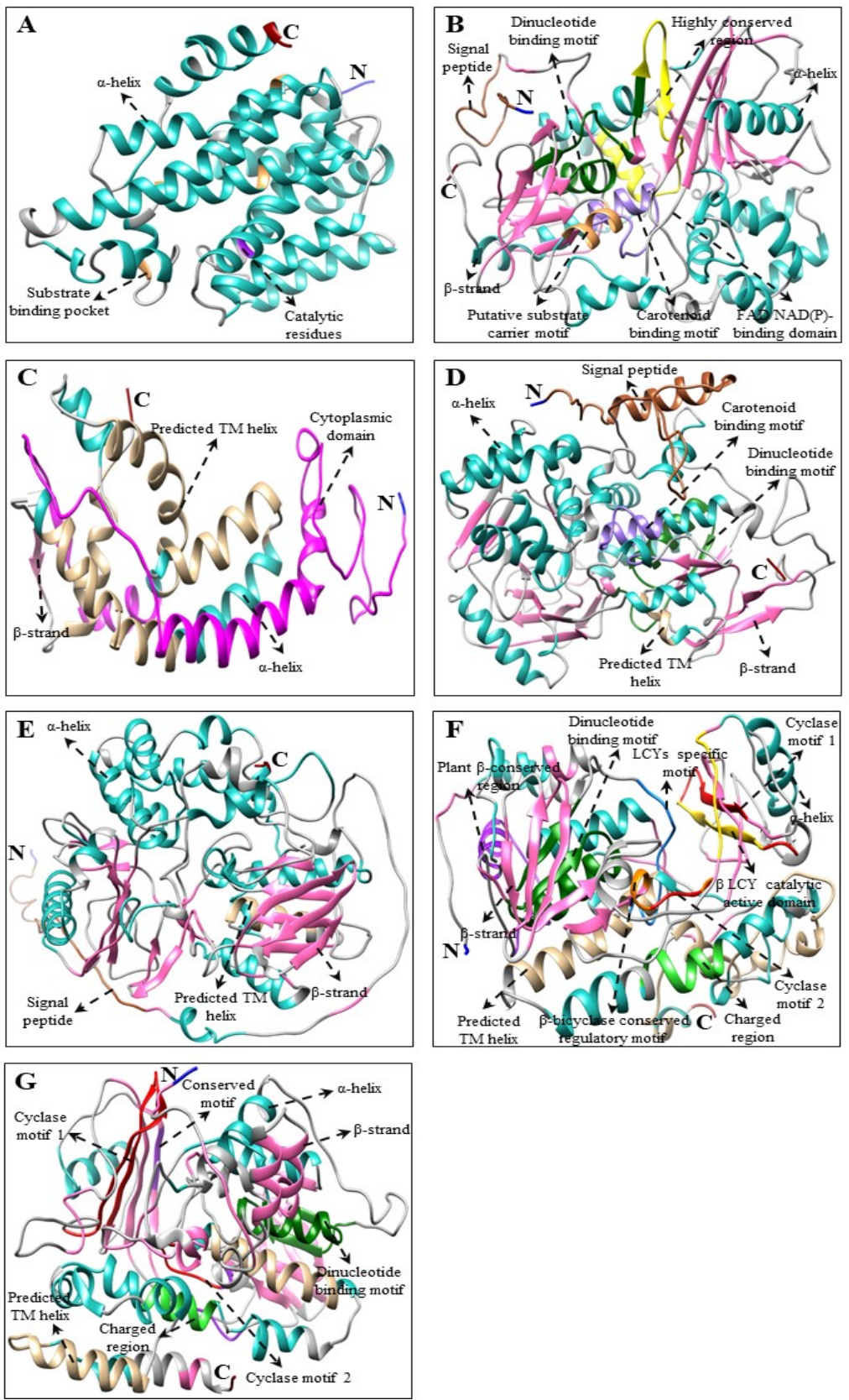

Figure 2. Three-dimensional structure of CBP genes of C. majus. (A) CmPSY, (B) CmPDS, (C) CmZ-ISO (partial ORF), (D) CmZDS, (E) CmCrtISO, (F) CmLCYB, and (G) CmLCYE structures were produced by using Chimera 1.14 software [76]. The amino $\left(\mathrm{NH}_{2}\right)$ and carboxyl $(\mathrm{COOH})$ termini are shown in blue and dark red, respectively. In these 3D structures, $\alpha$-helices are shown in light sea green whereas $\beta$-strands are shown in hot pink. Multiple alignments of each gene are shown in Figure S3. 

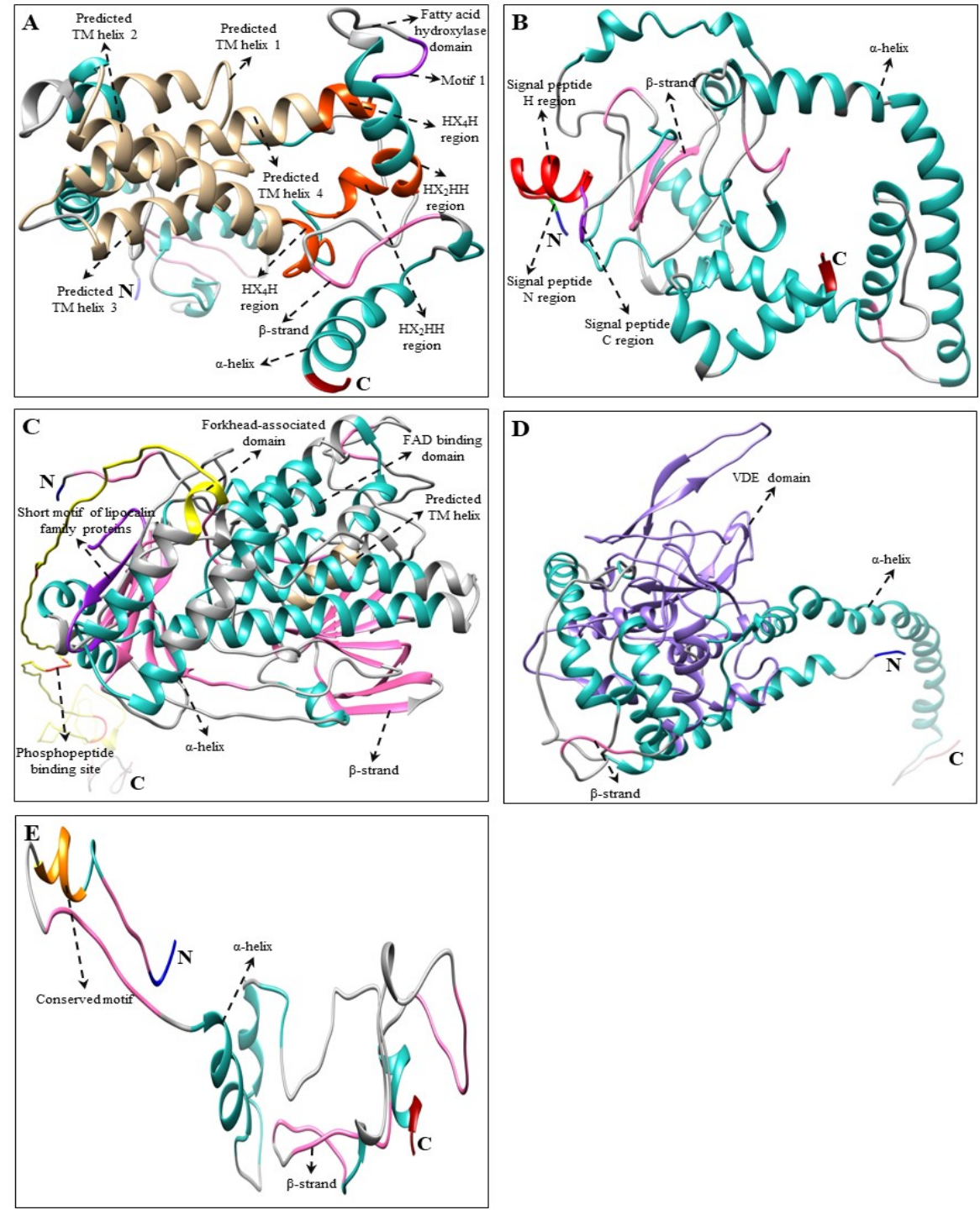

Figure 3. Three-dimensional structure of $\mathrm{XBP}$ genes of $\mathrm{C}$. majus. (A) $\mathrm{CmCHXB}$, (B) $\mathrm{CmCHXE}$ (partial ORF), (C) CmZEP, (D) CmVDE, and (E) CmCCS (partial ORF) structures were produced by using Chimera 1.14 software [76]. The amino $\left(\mathrm{NH}_{2}\right)$ and carboxyl $(\mathrm{COOH})$ termini are shown in blue and dark red, respectively. In these 3D structures, $\alpha$-helices are shown in light sea green whereas $\beta$-strands are sown in hot pink. Multiple alignments of each gene are shown in Figure S3.

The common genes responsible for both $\mathrm{CBP}$ and $\mathrm{XBP}$ are $\mathrm{CmCHXB}$ and $\mathrm{CmCHXE}$. $\mathrm{CmCHXB}$ consists of four histidine domains that might be helpful for the attachment of $\mathrm{Fe}^{2+}$ ion during hydroxylation $[29,77]$. In cucumber, the VDE gene consists of Cysrich, lipocalin, and Glu-rich domains in their structure [52]. The lipocalin domain is the binding site for the hydrophobic V [78]. The C- and N-terminal regions consist of a high number of Glu residues and proteins targeted to chloroplasts, respectively [78,79]. A similar protein structure was found in CmVDE protein sequences, which consist of these conserved domains (Figure 3 and Figure S3). CmZEP consists of a forkhead-associated (FHA) binding domain, two short motifs of lipocalin family proteins, and a FAD-binding domain in its structure. In addition, it has various phosphopeptide binding sites in its amino acid sequence. Similar domains and phosphopeptide binding sites were present in the amino acid sequences of higher plants, such as I. dentate and S. baicalensis [29,31]. In tiger lily (Lilium lancifolim), the FLEET motif was identified, which is essential for the $\beta$ and $\kappa$-cyclase activities of LICCS $[53,80,81]$. A similar FLEET motif was found in the amino acid sequence of CmCCS (Figure 3 and Figure S3). 

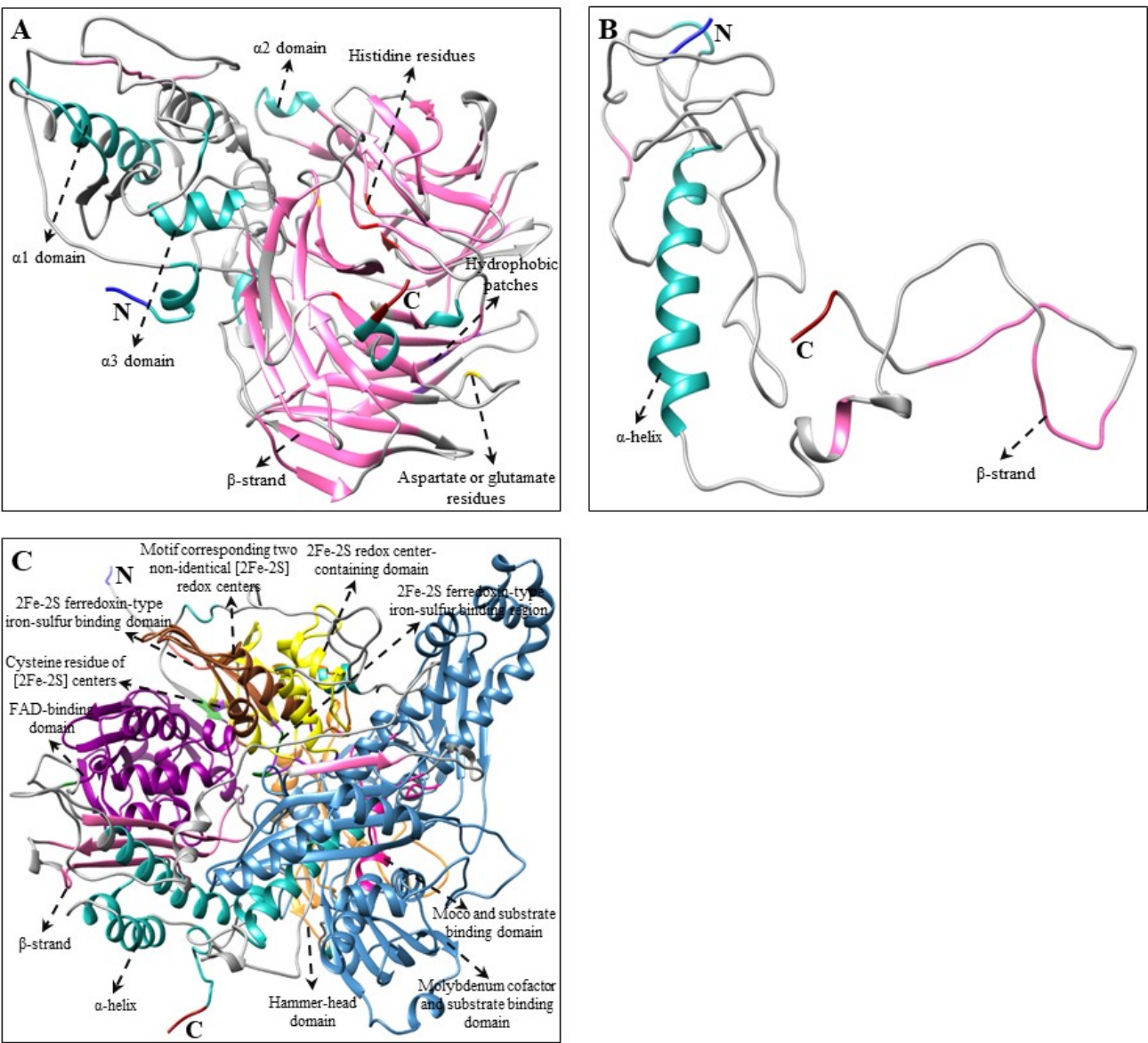

Figure 4. Three-dimensional structure of ABP genes of C. majus. (A) CmCCD, (B) CmNCED (partial $\mathrm{ORF}$ ), and (C) $\mathrm{CmAO}$ structures were produced by using Chimera 1.14 software [76]. The amino $\left(\mathrm{NH}_{2}\right)$ and carboxyl $(\mathrm{COOH})$ termini are shown in blue and dark red, respectively. In these 3D structures, $\alpha$-helices are shown in light sea green whereas $\beta$-strands are shown in hot pink. Multiple alignments of each gene are shown in Figure S3.

In XBP genes, $C m C C D$ and $C m N C E D$ have four highly conserved histidine residues (Figure 4 and Figure S3), similar to the structures of CCD4a, b1, and $c$ genes in Citrus plants [56]. Several studies have reported that these four histidine residues are helpful in coordinating the $\mathrm{Fe}^{2+}$ cofactor essential for activity and glutamate or aspartate moieties that help to fix positions of the histidine $[55,82,83]$. In Pisum sativum, the PsAO gene possesses a consensus sequence for two iron-sulfur centers, molybdenum cofactor (Moco) binding domain, and FAD-binding domain [84]. Similar conserved domains were displayed in the amino acid sequence of $C m A O$ (Figure 4 and Figure S3). The alignment and structural analysis showed that most of the C. majus' $\mathrm{CBP}, \mathrm{XBP}$, and $\mathrm{ABP}$ genes are highly conserved; and that the genes are most closely related to those of higher plants and algae. However, further comprehensive studies are required to recognize the functions of $C$. majus' $\mathrm{CBP}$, $\mathrm{XBP}$, and $\mathrm{ABP}$ proteins identified in this study.

\subsection{Subcellular Location Prediction of CBP, XBP, and ABP Genes by In Silico Analysis}

C. majus' $\mathrm{CBP}, \mathrm{XBP}$, and $\mathrm{ABP}$ sequences were analyzed using CELLO2GO, WoLF PSORT, TargetP 1.1, ChloroP 1.1, and Plant-PLoc free online programs to determine the subcellular location of these proteins. Most CBP, XBP, and ABP proteins, except CmPSY, were targeted to the chloroplast, whereas some proteins might also be targeted to various organelles, such as cytoplasm, endoplasmic reticulum, mitochondrion, nucleus, plasma membrane, and thylakoid membrane (Table 3). Similar results were obtained in several plants, such as A. thaliana, transgenic Ipomoea batatas, where most $\mathrm{CBP}, \mathrm{XBP}$, and $\mathrm{ABP}$ genes 
were localized within the chloroplast $[67,85,86]$. Therefore, we confirmed that all CBP, XBP, and $\mathrm{ABP}$ proteins in C. majus share highly conserved sequences with those in higher plants, so their subcellular location prediction also showed similar results.

Table 3. The subcellular-localization predictions of C. majus $\mathrm{CBP}, \mathrm{XBP}$, and $\mathrm{ABP}$ genes.

\begin{tabular}{|c|c|c|c|c|c|c|}
\hline Gene Names & CELLO2GO & WoLF PSORT & TargetP & ChloroP 1.1 & Plant-PLoc & Consensus Prediction \\
\hline CmPSY & MC & $\mathrm{MC}$ & Other & Other & NUC & MC/NUS/other \\
\hline CmPDS & $\mathrm{CP}$ & $\mathrm{CP}$ & $\mathrm{CP}$ & $\mathrm{CP}$ & $\mathrm{CP}$ & $\mathrm{CP}$ \\
\hline CmZ-ISO & PM & $\mathrm{CP}$ & $\mathrm{CP}$ & $\mathrm{CP}$ & $\mathrm{CP}$ & $\mathrm{CP} / \mathrm{PM}$ \\
\hline CmZDS & $\mathrm{CP}$ & $\mathrm{CP}$ & $\mathrm{CP}$ & $\mathrm{CP}$ & $\mathrm{CP}$ & $\mathrm{CP}$ \\
\hline $\mathrm{CmCrtISO}$ & $\mathrm{CP}$ & $\mathrm{CP}$ & $\mathrm{CP}$ & $\mathrm{CP}$ & $\mathrm{CP}$ & $\mathrm{CP}$ \\
\hline$C m L C Y B$ & MC & $\mathrm{CP}$ & Other & Other & $\mathrm{CP}$ & $\mathrm{CP} / \mathrm{MC} /$ other \\
\hline CmLCYE & PM & $\mathrm{CP}$ & $\mathrm{CP}$ & $\mathrm{CP}$ & $\mathrm{CP}$ & $\mathrm{CP} / \mathrm{PM}$ \\
\hline $\mathrm{CmCHXB}$ & $\mathrm{CP}$ & $\mathrm{CP}$ & $\mathrm{CP}$ & $\mathrm{CP}$ & $\mathrm{CP}$ & $\mathrm{CP}$ \\
\hline CmCHXE & $\mathrm{CP}$ & $\mathrm{CP}$ & $\mathrm{CP}$ & $\mathrm{CP}$ & $\mathrm{CP}$ & $\mathrm{CP}$ \\
\hline$C m Z E P$ & $\mathrm{CP}$ & Cytoplasmic & $\mathrm{CP}$ & Other & $\mathrm{CP}$ & $\mathrm{CP} /$ cytoplasmic/other \\
\hline$C m V D E$ & Cytoplasmic & ER & Thylakoid & Other & $\mathrm{CP}$ & $\mathrm{CP} / \mathrm{ER} /$ thylakoid/other \\
\hline CmCCS & $\mathrm{MC}^{1}$ & $\mathrm{CP} / \mathrm{MC}$ & $\mathrm{CP}$ & $\mathrm{CP}$ & $\mathrm{CP}$ & $\mathrm{CP} / \mathrm{MC}$ \\
\hline$C m C C D$ & $\mathrm{CP}$ & Cytoplasmic & Other & $\mathrm{CP}$ & $\mathrm{CP}$ & $\mathrm{CP} /$ cytoplasmic/other \\
\hline$C m N C E D$ & NUC & $\mathrm{CP}$ & Other & $\mathrm{CP}$ & $\mathrm{CP}$ & $\mathrm{CP} / \mathrm{NUC} /$ other \\
\hline $\mathrm{CmAO}$ & $\mathrm{CP}$ & Cytoplasmic & Other & Other & $\mathrm{CP}$ & $\mathrm{CP} /$ cytoplasmic/other \\
\hline
\end{tabular}

Note: CP—chloroplast; ER—endoplasmic reticulum; MC—mitochondria; NUC—nucleus; PM—plasma membrane.

\section{5. $C B P, X B P$, and ABP Gene Expression Levels in Different Parts of C. majus}

The qRT-PCR results showed that the $\mathrm{CBP}, \mathrm{XBP}$, and $\mathrm{ABP}$ genes were integrally expressed in C. majus. Among these, the highest expression level was observed in CmZDS, whereas the lowest expression level was found in $C m A O$ (Figure 5). In the CBP genes, most genes (CmPDS, CmZ-ISO, CmCrtISO, CmLCYB, and CmLCYE) were highly expressed in flowers. CmZDS was significantly higher in leaves, which was 7.97-, 145.11-, and 216.08-times higher than those in flowers, stems, and roots, respectively. In contrast, CmPSY had the highest expression in roots, followed by that in stems, flowers, and leaves. In addition, most XBP genes ( $\mathrm{CmCHXB}$ and $\mathrm{CmCHXE}$ ) were strongly upregulated in flowers, whereas CmZEP and CmVDE were significantly upregulated in leaves. The expression of CmVDE was the highest in leaves, which was 4.30-, 5.78-, and 288.80- times higher than that in flowers, stems, and roots, respectively. However, CmCCS had a higher expression level in roots when compared with the other parts. In ABP genes, $C m C C D$ was significantly expressed in leaves, which was 9.74-, 10.26-, and 26.69- times higher than that in roots, stems, and flowers, respectively, whereas $C m N C E D$ and $C m A O$ had an increased expression in stems, and roots, respectively (Figure 5).

A similar result was obtained in most studies, where most CBP genes were highly expressed in the flowers and leaves of plants, such as Brassica rapa [87] and N. officinale (unpublished data), when compared with the other plant parts. In this study, the expression of CBP genes showed that most genes had the same role as their orthologs in other species. For example, [88] stated that the genes responsible for CBP (AtPSY, AtPDS, AtZDS, and $A t Z E P)$ play a vital role. Overall, the results of this study showed that most $\mathrm{CBP}, \mathrm{XBP}$, and $\mathrm{ABP}$ genes had the highest expression in flowers (CmPDS, CmZ-ISO, CmCrtISO, CmLCYE, $C m L C Y B, C m C H X B$, and $C m C H X E$ ), followed by that in leaves (CmZDS, CmZEP, CmVDE, and $C m C C D)$, root $(C m P S Y, C m A O$, and $C m C C S)$ and stems (CmNCED). This expression analysis of CBP genes will contribute to future genetic studies on in $C$. majus to enhance their carotenoid content through metabolic engineering. 


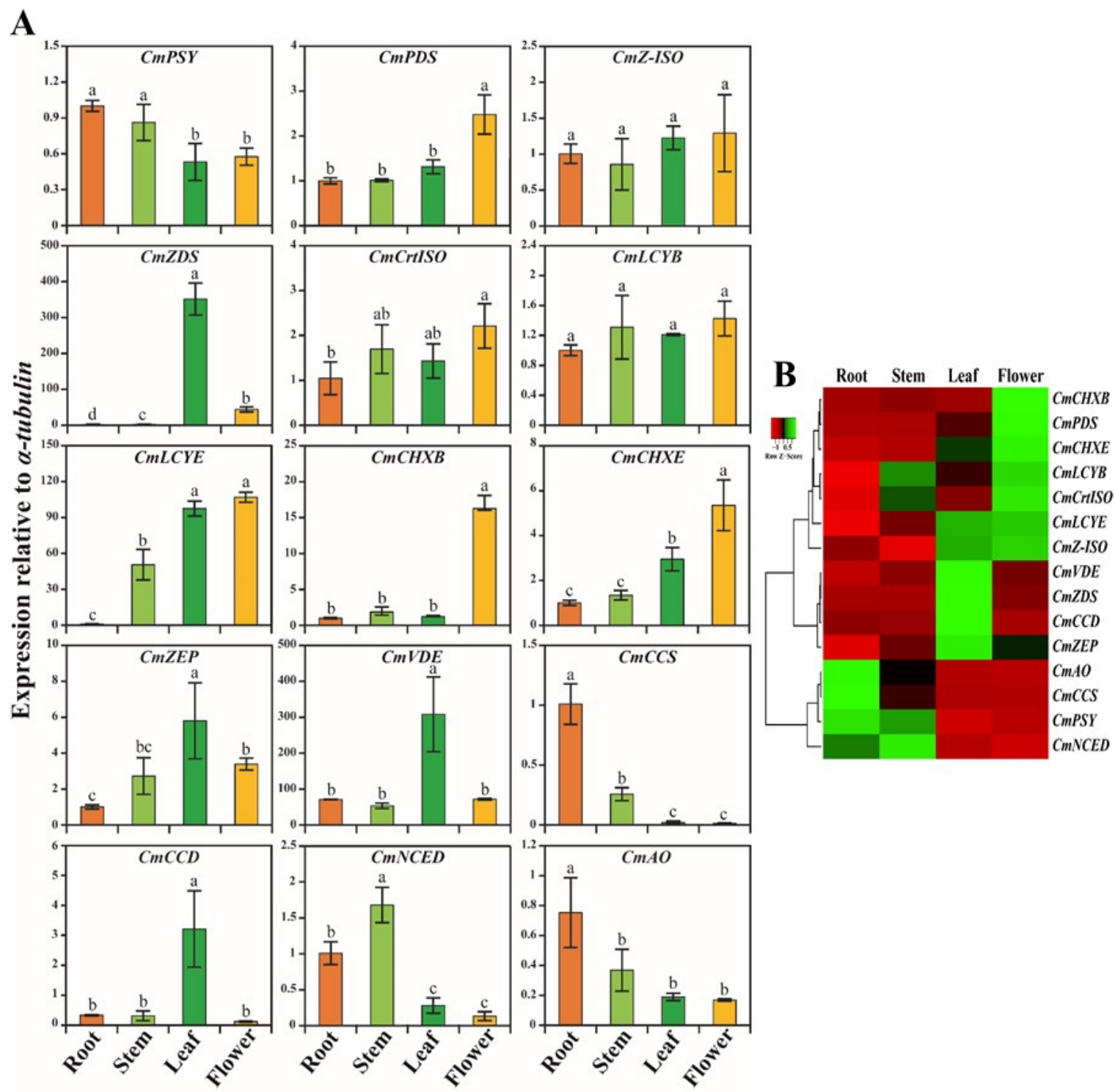

Figure 5. Relative gene expression profiles of eleven $\mathrm{CBP}, \mathrm{XBP}$, and $\mathrm{ABP}$ genes of Chelidonium majus. (A) Expression levels of $\mathrm{CBP}, \mathrm{XBP}$, and $\mathrm{ABP}$ genes were examined in different organs such as leaf, stem, root, and flower of Chelidonium majus using qRT-PCR. Letters a-e denotes significant differences $(p<0.05)$. (B) Heat map showing the expression profiles of CBP, $\mathrm{XBP}$, and $\mathrm{ABP}$ genes in five different organs of Chelidonium majus. The heat map was constructed using fold-change values gained from qRT-PCR. The tree view of hierarchical clustering was used to display the organ-specific expression of CBP, $\mathrm{XBP}$, and $\mathrm{ABP}$ genes. A gradient color bar at the top is used to show whether the CBP, XBP, and ABP genes are up-regulated (red) or down-regulated (green).

\subsection{Carotenoid and Xanthophyll Level in Different Parts of C. majus}

Carotenoid levels were analyzed using HPLC. Eight different types of carotenoids were identified in different parts of $C$. majus (Figure 6). The total carotenoid content ranged from 4.667-1086.43 $\mu \mathrm{g} / \mathrm{g}$ of dry weight (DW) in different parts of C. majus. The leaves showed the highest total carotenoid content (1086.43 $\mu \mathrm{g} / \mathrm{g}$ DW), which was 1.87-, 12.87-, and 232.79- times higher than that in flowers, stems, and roots, respectively. Among the nine carotenoids, six carotenoids namely lutein, zeaxanthin, $13 Z-\beta$-carotene, $\alpha$-carotene, E- $\beta$ carotene, and 9Z- $\beta$-carotene, had the highest accumulation in leaves (Figure 6). Specifically, lutein, zeaxanthin, 13Z- $\beta$-carotene, $\alpha$-carotene, E- $\beta$-carotene, and 9Z- $\beta$-carotene were significantly higher in leaves than in other plant parts. 

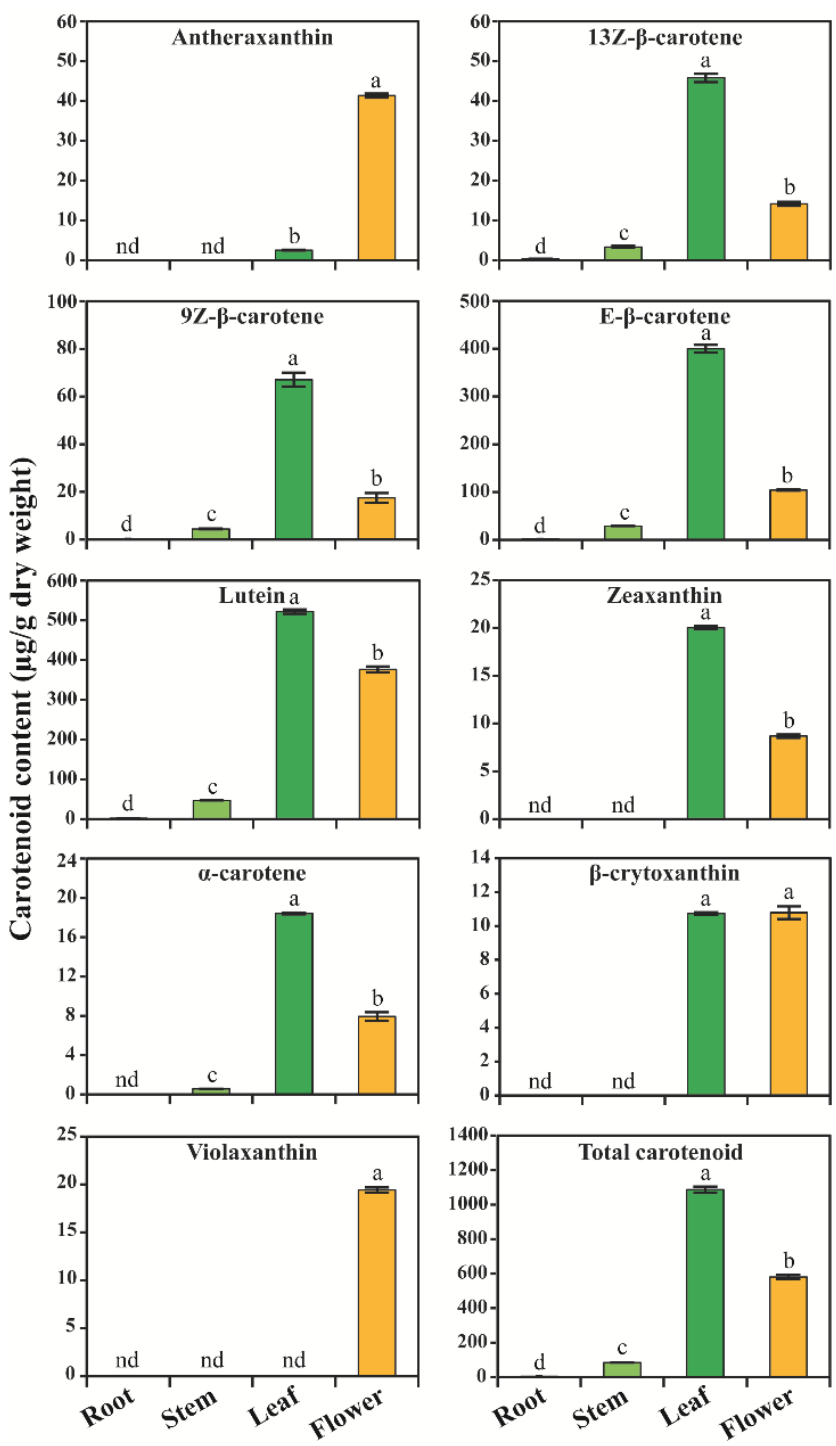

Figure 6. Carotenoid content in the different organs of Chelidonium majus. For HPLC analysis, samples were harvested from 3-month-old plants. Results are given as the means of triplicates \pm standard deviation. Letters a-e denotes significant differences $(p<0.05)$. nd: not detected.

Among the carotenoids, lutein, 13Z- $\beta$-carotene, E- $\beta$-carotene, and 9Z- $\beta$-carotene were detected in all plant organs. Among these, the lutein content was higher in leaves, which was 1.39-, 11.03-, and 236.23- times higher than that in flowers, stems, and roots, respectively, whereas the E- $\beta$-carotene level in leaves was 3.84-, 13.90-, and 220.14- times higher than that in flowers, stems, and roots, respectively. Similarly, the 9Z- $\beta$-carotene level was the highest in leaves, and it was 3.84-, 15.05-, and 240.51- times higher than that in flowers, stems, and roots, respectively. Zeaxanthin and $\beta$-crytoxanthin were detected only in flowers and leaves. Violaxanthin was detected only in flowers, whereas the neoxanthin content was not detected in any of the plant organs. The $\alpha$-carotene content $(\mu \mathrm{g} / \mathrm{g}$ DW) was the highest in leaves (18.41), followed by that in flowers (7.93) and stems (0.56), and it was not present in roots. Interestingly, the antheraxanthin content was significantly higher in flowers than in leaves, and it was not detected in roots and stems. Among the individual carotenoids, antheraxanthin, $\beta$-crytoxanthin, $\alpha$-carotene, and violaxanthin had the lowest content in the different parts of $C$. majus (Figure 6). These findings were similar to those in previous studies on M. charantia [89-91], B. rapa [92], C. majus [9], and Allium sativum [90]. Similar results were obtained in N. officinale, as its leaves also had the highest accumulation of carotenoids when compared with other plant organs (unpublished 
data). Thus, the leaves of $C$. majus had the highest carotenoid content when compared with other plant organs.

This study showed that the highest transcription of CBP, XBP, and ABP genes was found in flowers (Figure 5), whereas an increased carotenoid and xanthophyll content was achieved in the leaves of $C$. majus (Figure 6). This showed that the CBP, XBP, and ABP gene expression and the pattern of carotenoid and xanthophyll accumulation were not correlated, indicating that the enhanced transcriptional expression of genes does not always lead to the highest accumulation of carotenoids $[57,66]$. This might be due to the regulation of $\mathrm{CBP}, \mathrm{XBP}$, and $\mathrm{ABP}$ at multiple levels; the pathways are not only controlled at the transcriptional level but also at the translational level [93,94]. Furthermore, the CBP, $\mathrm{XBP}$, and $\mathrm{ABP}$ gene expressions are regulated by a group of cis-regulatory elements present in the upstream promoter region and untranslated regions $[95,96]$. In addition, protein modification might be another one of the reasons for the inequitable accumulation pattern of carotenoids and xanthophylls and $\mathrm{CBP}, \mathrm{XBP}$, and $\mathrm{ABP}$ gene expressions [97].

Due to the significant importance of the $\mathrm{CBP}, \mathrm{XBP}$, and $\mathrm{ABP}$ metabolism and function in the plant's development, physiology, ecology, and evolution, we had thoroughly studied all those genes in these pathways. In recent years, much research has been focused on carotenoid accumulation at multiple regulatory levels such as transcriptional, posttranscriptional and translation modification, storage, degradation of carotenoids, and feedback regulation of the end products [23]. For this reason, identification of CBP, XBP, and ABP genes from the transcriptomic data, characterization of those genes by sophisticated bioinformatics approach and analytical tools, and also understanding the expression level of those genes will help to uncover the relationship between metabolomics and transcriptomics profiles [23,98-101]. Identifying the complete pathway and 3D structure of $\mathrm{CBP}, \mathrm{XBP}$, and $\mathrm{ABP}$ genes will be helpful to manipulate the gene, engineer the potential genes, and transform the multiple $\mathrm{CBP}, \mathrm{XBP}$, and $\mathrm{ABP}$ genes instantaneously into the host plants for the improvement of carotenoid biosynthesis and enhance the novel or desired carotenoid products in stable crops [102,103]. In addition, subcellular localization analysis of the whole $\mathrm{CBP}, \mathrm{XBP}$, and $\mathrm{ABP}$ will help to achieve a deep understanding of the assembly of each gene in different organelles of the plants [103].

\section{Materials and Methods}

\subsection{Plant Materials}

Chelidonium majus seeds were acquired from an experimental farm of Chungnam National University, Daejeon, Republic of Korea. The seeds were placed in a pot filled with commercial perlite and allowed to grow for three months in the greenhouse of Chungnam National University (Daejeon, Korea). The plants were sprayed with water every two days. The different plant organs (leaves, stems, roots, and flowers) were harvested, flash-frozen in liquid nitrogen, and stored at $-80{ }^{\circ} \mathrm{C}$ until further analysis. Each sample was collected in triplicates.

\subsection{Identification and Sequence Analysis of $C B P, X B P$, and $A B P$ Genes}

$\mathrm{CBP}, \mathrm{XBP}$, and $\mathrm{ABP}$ gene sequences were identified from the $C$. majus transcriptomic data (62 $\mathrm{Mb}$ raw reads, average length of 76 nucleotides per reads) obtained in our laboratory. An Illumina NextSeq500 platform was used to analyze the cDNA using the commercial service of LAS company (Gimpo, Korea). Then, the retrieved CBP, XBP, and $\mathrm{ABP}$ sequences were subjected to an online Basic Local Alignment Search Tool (BLAST) on an NCBI database. The sequences were also analyzed using PFAM [104] and Conserved Domain Database (CCD) [105] on the NCBI databases to predict the putative signature motifs of the protein sequences. Secondary structure and signal peptide analyses were conducted using a SOPMA program [106] and SignalP 4.0 server [107], respectively. The predicted subcellular locations of the CBP proteins were identified using CELLO [108], ChloroP 1.1 [109], TargetP 1.1 [110], and WoLF PSORT [111] tools. Then, the theoretical pI 
(isoelectric point)/molecular weight (MW) was calculated by using the Compute $\mathrm{pI} / \mathrm{MW}$ tool on an ExPASy platform [112].

\subsection{Structural Analysis of $C B P, X B P$, and $A B P$ Genes}

Multiple sequence alignment was carried out using a BioEdit 7.2.5 program [113]. The CBP, $\mathrm{XBP}$, and ABP protein sequences were submitted to Phyre2 for homology modeling and three-dimensional (3D) structural analysis [114]. Then, 3D structures were predicted using a Chimera 1.14 software [76]. The conserved signature motifs among the $\mathrm{CBP}, \mathrm{XBP}$, and $\mathrm{ABP}$ genes were found using a MEME tool [115].

\subsection{Phylogenetic Analysis and Percent Identity Matrix}

A phylogenetic tree was constructed using MEGA 7.0 [116]. Neighbor-joining (NJ) phylogenetic trees [117] were constructed using a Poisson model. The robustness of the trees was estimated by performing 1000 bootstrap replicates [118]. The percent identity matrix between the CBP, XBP, and ABP amino acid sequences was calculated using clustal omega [119], and identities were calculated from the pairwise multiple sequence alignment [120].

\subsection{RNA Extraction and cDNA Synthesis}

Total RNA extraction was conducted on the leaves, stems, roots, and flowers of the plants. Each sample was ground into a fine powder using a mortar and pestle with the help of liquid nitrogen. Then, $0.1 \mathrm{~g}$ of each sample was transferred to a new $1.5-\mathrm{mL}$ microcentrifuge tube. A Plant Total RNA Mini Kit (Geneaid, Taiwan) was used to extract the total RNA, following the manufacturer's protocols. The RNA quality and concentration were determined using $1 \%$ agarose gel electrophoresis and NanoVue Plus spectrophotometer (GE Health Care Life Sciences, Chicago, IL, USA), respectively. The extracted total RNAs were reverse transcribed into cDNA using a ReverTra Ace- $\alpha$-kit (Toyobo Co. Ltd., Osaka, Japan), following the manufacturer's protocols. The synthesized cDNA templates were diluted 20-fold with RNase-free water for further experiments.

\section{6. $C B P, X B P$, and $A B P$ Genes Expression}

For qRT-PCR, $\alpha$-tubulin gene was used as an internal control. Specific primers for the $\mathrm{CBP}, \mathrm{XBP}, \mathrm{ABP}$, and $\alpha$-tubulin genes were designed using a Gene Runner version 5 software (www.generunner.net, accessed on 10 July 2021). The primers used in this study are shown in Table S1. The relative gene expression level was calculated using $\alpha$-tubulin. The qRT-PCR conditions were similar to the protocol described by Tuan et al. [31]. The gene expression level was calculated using a $\Delta C t$ method [121,122]. The visualization and expression analysis of $\mathrm{CBP}, \mathrm{XBP}$, and $\mathrm{ABP}$ genes in the heatmap and hierarchical clustering was conducted using an online heat mapper software [123]. All PCR reactions were carried out in triplicates.

\subsection{Carotenoid Extractions and HPLC Analysis}

Carotenoids were extracted and analyzed by following the protocol described by Park et al. [124]. For HPLC analysis, $3 \mathrm{~mL}$ of ethanol containing $0.1 \%$ ascorbic acid $(w / v)$ was added to $0.3 \mathrm{~g}$ of finely powdered samples. This was mixed well and incubated at $85{ }^{\circ} \mathrm{C}$ for $10 \mathrm{~min}$ in a water bath. For saponification, $120 \mu \mathrm{L}$ of potassium hydroxide $(80 \% \mathrm{w} / \mathrm{v})$ was added. To stop the reaction, the samples were flash-frozen on ice for $5 \mathrm{~min}$. Then, $1.5 \mathrm{~mL}$ of ice-cold water and $0.05 \mathrm{~mL}$ of $\beta$-apo- $8^{\prime}$-carotenal internal standard $(1.25 \mu \mathrm{g})$ were added. Carotenoids were re-extracted thrice using $1.5 \mathrm{~mL}$ of hexane and were centrifuged each time at $12,000 \mathrm{rpm}$ for $5 \mathrm{~min}$ at $4{ }^{\circ} \mathrm{C}$. The extracts were dried under nitrogen stream and were re-dissolved in $0.25 \mathrm{~mL}$ of dichloromethane/methanol $(50: 50 \mathrm{v} / \mathrm{v})$. These mixtures were filtered through a polytetrafluoroethylene (PTFE) membrane filter $(0.50 \mu \mathrm{m}$, Advantec, Tokyo, Japan) into amber screw cap vials (Thermo Fisher Scientific, Waltham, MA, USA). The HPLC conditions and gradient programs were similar to a previous protocol [124]. The individual carotenoid concentrations were quantified using their retention time and 
co-elution with $\beta$-apo- $8^{\prime}$-carotenal; these were quantitated based on standard calibration curves. All standards were obtained from CaroteNature (Lupsingen, Switzerland).

\subsection{Statistical Analysis}

In this study, all results are expressed as the mean \pm standard deviation (SD) of three independent biological replicates. All data were analyzed by analysis of variance (ANOVA) with Duncan's multiple range tests (DMRT) to compare the means, with a significance level of $p<0.05$ using the Statistical Analysis System version 9.2 (SAS Institute Inc., Cary, NC, USA, 2009).

\section{Conclusions}

This is the first report to identify and characterize the CBP genes in C. majus using a molecular approach. Using in silico analysis, we identified and characterized seven CBP, five $\mathrm{XBP}$, three $\mathrm{ABP}$ genes in $C$. majus, and among these, eleven genes possess a full ORF, whereas four genes had a partial ORF. By using bioinformatics tools including multiple alignments and 3D structure prediction, we showed that $C$. majus CBP gene sequences shared high similarity with other higher plants and microalgae. In addition, subcellular localization prediction showed that most of the C. majus CBP genes were localized in the chloroplast. Differential expression of CBP genes showed an organ-specific variation at the transcriptional level with most CBP genes highly up-regulated in the flowers. Furthermore, the highest accumulation of carotenoids was observed in C. majus leaves, whereas other organs showed less accumulation. This indicates that $\mathrm{CBP}, \mathrm{XBP}$, and $\mathrm{ABP}$ is complex and does not just change based on alterations in mRNA expression. Differences between the gene expression levels and carotenoid accumulation may depend on signals that dictate whether CBP genes can be activated in various parts of plants at different stages. This study will therefore improve our understanding of the molecular mechanisms regulating carotenoid accumulation in C. majus, and this can subsequently serve as a valuable resource for genetic manipulation to increase the nutritional content of $C$. majus. In future, further studies are necessary to achieve genome-wide identification of the CBP gene in C. majus genome which will be beneficial to identify more homologues, gene family, and alleles.

Supplementary Materials: The following are available online at https: / www.mdpi.com/article / 10.3390/plants10081753/s1, Figure S1: (A-O): The nucleotide sequence and deduced amino acid sequences of $\mathrm{CBP}, \mathrm{XBP}$, and $\mathrm{ABP}$ genes. Figure S2: (A-O): Phylogeny and conserved motif analysis of deduced $\mathrm{CBP}, \mathrm{XBP}$, and $\mathrm{ABP}$ amino acid sequences along with other $\mathrm{CBP}$ sequences. Figure S3: (A-O): Amino acid alignment of CBP, XBP, and ABP genes with other CBP genes. Table S1: List of primers used in qRT-PCR analysis to determine mRNA expression levels of $C$. majus $\mathrm{CBP}, \mathrm{XBP}$, and ABP genes. Table S2: Analysis of CBP, XBP, and ABP gene sequences using the SignalP program.

Author Contributions: S.U.P. and J.K.K. conceived the study; R.S., H.J.Y., C.H.P., M.C., H.K., and J.E.S. performed the experiments and analyzed the data; R.S. performed computational analysis and writing original draft; R.S., S.U.P., and J.K.K. produced the writing — review \& editing. All authors have read and agreed to the published version of the manuscript.

Funding: This work was supported by the Incheon National University Research Grant in 2021, Republic of Korea, and a grant from the Next-generation BioGreen 21 Program (PJ015665), Korea.

Institutional Review Board Statement: Not applicable

Informed Consent Statement: Not applicable

Data Availability Statement: Data reported are available in the Supplementary Materials.

Conflicts of Interest: The authors declare no conflict of interest.

\section{References}

1. Orvos, P.; Virág, L.; Tálosi, L.; Hajdú, Z.; Csupor, D.; Jedlinszki, N.; Szél, T.; Varró, A.; Hohmann, J. Effects of Chelidonium majus extracts and major alkaloids on hERG potassium channels and on dog cardiac action potential-A safety approach. Fitoterapia 2015, 100, 156-165. [CrossRef] 
2. Colombo, M.L.; Bosisio, E. Pharmacological activities of Chelidonium majus L. (papaveraceae). Pharmacol. Res. 1996, 33, 127-134. [CrossRef]

3. Horváth, G.; Molnár, P.; Farkas, A.; Szabó, L.G.; Turcsi, E.; Deli, J. Separation and identification of carotenoids in flowers of Chelidonium majus L. and inflorescences of Solidago canadensis L. Chromatographia 2010, 71, 103-108. [CrossRef]

4. Kędzia, B.; Łożykowska, K.; Gryszczyńska, A. Skład chemiczny i zawartość substancji biologicznie aktywnych w Chelidonium majus L. Postępy Fitoterapii 2013, 3, 174-181.

5. Mikołajczak, P.Ł.; Kędzia, B.; Ożarowski, M.; Kujawski, R.; Bogacz, A.; Bartkowiak-Wieczorek, J.; Białas, W.; Gryszczyńska, A.; Buchwald, W.; Szulc, M. Evaluation of anti-inflammatory and analgesic activities of extracts from herb of Chelidonium majus L. Cent. Eur. J. Immunol. 2015, 40, 400. [CrossRef]

6. Nawrot, R.; Zauber, H.; Schulze, W.X. Global proteomic analysis of Chelidonium majus and Corydalis cava (Papaveraceae) extracts revealed similar defense-related protein compositions. Fitoterapia 2014, 94, 77-87. [CrossRef] [PubMed]

7. Stancic-Rotaru, M.; Mititelu, M.; Crasmaru, M.; Balaban, D. Spectroanalytical profile of flavonoids from Chelidonium majus L. Rom. Biotechnol. Lett. 2002, 8, 1093-1100.

8. Gilca, M.; Gaman, L.; Panait, E.; Stoian, I.; Atanasiu, V. Chelidonium majus-An integrative review: Traditional knowledge versus modern findings. J. Complement. Med. Res. 2010, 17, 241-248. [CrossRef]

9. Khodabande, Z.; Jafarian, V.; Sariri, R. Antioxidant activity of Chelidonium majus extract at phenological stages. Appl. Biol. Chem. 2017, 60, 497-503. [CrossRef]

10. Orland, A.; Knapp, K.; König, G.; Ulrich-Merzenich, G.; Knöß, W. Combining metabolomic analysis and microarray gene expression analysis in the characterization of the medicinal plant Chelidonium majus L. Phytomedicine 2014, 21, 1587-1596. [CrossRef]

11. Wouters, A.; Lardon, F.; Gravekamp, C.; Apers, S.; Pieters, L. In vitro and in vivo investigations on the antitumour activity of Chelidonium majus. Phytomedicine 2015, 22, 1279-1287.

12. Zielińska, S.; Czerwińska, M.E.; Dziagwa-Becker, M.; Dryś, A.; Kucharski, M.; Jezierska-Domaradzka, A.; Płachno, B.J.; Matkowski, A. Modulatory effect of Chelidonium majus extract and its alkaloids on LPS-stimulated cytokine secretion in human neutrophils. Molecules 2020, 25, 842. [CrossRef] [PubMed]

13. Arora, D.; Sharma, A. A review on phytochemical and pharmacological potential of genus Chelidonium. Pharmacogn. J. 2013, 5, 184-190. [CrossRef]

14. Molnár, P.; Kawase, M.; Motohashi, N. Isolation, crystallization and handling of carotenoids and (E/Z)-isomerization of carotenoids. In Functional Polyphenols and Carotenes with Antioxidative Action; Motohashi, N., Ed.; Research Signpost: Trivandrum, India, 2005; pp. 111-131.

15. Sathasivam, R.; Radhakrishnan, R.; Kim, J.K.; Park, S.U. An update on biosynthesis and regulation of carotenoids in plants. S. Afr. J. Bot. 2020, 1-13. [CrossRef]

16. Sathasivam, R.; Kermanee, P.; Roytrakul, S.; Juntawong, N. Isolation and molecular identification of $\beta$-carotene producing strains of Dunaliella salina and Dunaliella bardawil from salt soil samples by using species-specific primers and internal transcribed spacer (ITS) primers. Afr. J. Biotechnol. 2012, 11, 16677-16687.

17. Sathasivam, R.; Pongpadung, P.; Praiboon, J.; Chirapart, A.; Trakulnaleamsai, S.; Roytrakul, S.; Juntawong, N. Optimizing NaCl and KNO3 concentrations for high $\beta$-carotene production in photobioreactor by Dunaliella salina KU11 isolated from saline soil sample. Chiang Mai J. Sci. 2018, 45, 106-115.

18. Sathasivam, R.; Praiboon, J.; Chirapart, A.; Trakulnaleamsai, S.; Kermanee, P.; Roytrakul, S.; Juntawong, N. Screening, phenotypic and genotypic identification of $\beta$-carotene producing strains of Dunaliella salina from Thailand. Indian J. Geo-Mar. Sci. 2014, $43,2198-2216$.

19. Sathasivam, R.; Radhakrishnan, R.; Hashem, A.; Abd_Allah, E.F. Microalgae metabolites: A rich source for food and medicine. Saudi J. Biol. Sci. 2019, 26, 709-722. [CrossRef]

20. Sathasivam, R.; Ki, J.-S. A review of the biological activities of microalgal carotenoids and their potential use in healthcare and cosmetic industries. Mar. Drugs 2018, 16, 26. [CrossRef]

21. Sathasivam, R.; Ki, J.-S. Differential transcriptional responses of carotenoid biosynthesis genes in the marine green alga Tetraselmis suecica exposed to redox and non-redox active metals. Mol. Biol. Rep. 2019, 46, 1167-1179. [CrossRef]

22. Hughes, D.A. Effects of carotenoids on human immune function. Proc. Nutr. Soc. 1999, 58, 713-718. [CrossRef] [PubMed]

23. Stanley, L.; Yuan, Y.-W. Transcriptional regulation of carotenoid biosynthesis in plants: So many regulators, so little consensus. Front. Plant Sci. 2019, 10, 1017. [CrossRef] [PubMed]

24. Flowerika, A.A.; Kumar, J.; Thakur, N.; Pandey, A.; Pandey, A.K.; Upadhyay, S.K.; Tiwari, S. Characterization and expression analysis of phytoene synthase from bread wheat (Triticum aestivum L.). PLoS ONE 2016, 11, e0162443. [CrossRef] [PubMed]

25. Karvouni, Z.; John, I.; Taylor, J.E.; Watson, C.F.; Turner, A.J.; Grierson, D. Isolation and characterization of a melon cDNA clone encoding phytoene synthase. Plant Mol. Biol. 1995, 27, 1153-1162. [CrossRef]

26. Kato, M.; Ikoma, Y.; Matsumoto, H.; Sugiura, M.; Hyodo, H.; Yano, M. Accumulation of carotenoids and expression of carotenoid biosynthetic genes during maturation in citrus fruit. Plant Physiol. 2004, 134, 824-837. [CrossRef]

27. Kim, I.J.; Ko, K.C.; Kim, C.S.; Chung, W.I. Isolation and expression patterns of a cDNA encoding phytoene synthase in citrus. J. Plant Physiol. 2001, 158, 795-800. [CrossRef]

28. Obrero, A.; Gonzalez-Verdejo, C.I.; Roman, B.; Gomez, P.; Die, J.V.; Ampomah-Dwamena, C. Identification, cloning, and expression analysis of three phytoene synthase genes from Cucurbita pepo. Biol. Plant. 2015, 59, 201-210. [CrossRef] 
29. Reddy, C.S.; Lee, S.H.; Yoon, J.S.; Kim, J.K.; Lee, S.W.; Hur, M.; Koo, S.C.; Kim, M.R.; Lee, W.M.; Jang, J.K.; et al. Molecular cloning and characterization of carotenoid pathway genes and carotenoid content in Ixeris dentata var. albiflora. Molecules 2017, 22, 1449. [CrossRef]

30. Salvini, M.; Bernini, A.; Fambrini, M.; Pugliesi, C. cDNA cloning and expression of the phytoene synthase gene in sunflower. J. Plant Physiol. 2005, 162, 479-484. [CrossRef]

31. Tuan, P.A.; Kim, Y.B.; Kim, J.K.; Arasu, M.V.; Al-Dhabi, N.A.; Park, S.U. Molecular characterization of carotenoid biosynthetic genes and carotenoid accumulation in Scutellaria baicalensis Georgi. J. Exp. Clin. Sci. 2015, 14, 146-157.

32. Zhang, J.C.; Tao, N.G.; Xu, Q.; Zhou, W.J.; Cao, H.B.; Xu, J.A.; Deng, X.X. Functional characterization of Citrus PSY gene in Hongkong kumquat (Fortunella hindsii Swingle). Plant Cell Rep. 2009, 28, 1737-1746. [CrossRef]

33. Li, C.; Ji, J.; Wang, G.; Li, Z.D.; Wang, Y.R.; Fan, Y.J. Over-expression of LcPDS, LcZDS, and LcCRTISO, genes from wolfberry for carotenoid biosynthesis, enhanced carotenoid accumulation, and salt tolerance in tobacco. Front. Plant Sci. 2020, 11, 119. [CrossRef] [PubMed]

34. Shen, Q.Q.; Li, L.X.; Zhan, P.L.; Wang, Q. Cloning and functional characterization of phytoene desaturase in Andrographis paniculata. Zhongguo Zhong Yao Za Zhi 2015, 40, 3760-3765. [PubMed]

35. Chen, Y.; Li, F.Q.; Wurtzel, E.T. Isolation and characterization of the Z-ISO gene encoding a missing component of carotenoid biosynthesis in plants. Plant Physiol. 2010, 153, 66-79. [CrossRef] [PubMed]

36. Zhang, C.; Wang, Y.G.; Fu, J.X.; Bao, Z.Y.; Zhao, H.B. Transcriptomic analysis and carotenogenic gene expression related to petal coloration in Osmanthus fragrans 'Yanhong Gui'. Trees 2016, 30, 1207-1223. [CrossRef]

37. Araya-Garay, J.; Feijoo-Siota, L.; Veiga-Crespo, P.; Sanchez-Perez, A.; Gonzalez Villa, T. Cloning and functional expression of zeta-carotene desaturase, a novel carotenoid biosynthesis gene from Ficus carica. Int. J. Microbiol. Adv. Immunol. 2014, 2, 32-40.

38. Flores-Ortiz, C.; Alvarez, L.M.; Undurraga, A.; Arias, D.; Duran, F.; Wegener, G.; Stange, C. Differential role of the two ל-carotene desaturase paralogs in carrot (Daucus carota): ZDS1 is a functional gene essential for plant development and carotenoid synthesis. Plant Sci. 2020, 291, 110327. [CrossRef]

39. Kim, I.J.; Nam, T.S.; Kim, C.S.; Song, K.J.; Lee, D.H. Isolation and expression patterns of a zeta-carotene desaturase gene from citrus. Hortic. Environ. Biotechnol. 2010, 51, 551-555.

40. Li, Z.D.; Wu, G.X.; Ji, J.; Wang, G.; Tian, X.W.; Gao, H.L. Cloning and expression of a ל-carotene desaturase gene from Lycium chinense. J. Genet. 2015, 94, 287-294. [CrossRef]

41. Li, P.R.; Zhang, S.J.; Zhang, S.F.; Li, F.; Zhang, H.; Liu, X.Y.; Wu, J.; Wang, X.W.; Sun, R.F. Carotenoid identification and molecular analysis of carotenoid isomerase-encoding BrCRTISO, the candidate gene for inner leaf orange coloration in Chinese cabbage. Mol. Breed. 2015, 35, 72. [CrossRef]

42. Pinheiro, T.T.; Peres, L.E.P.; Purgatto, E.; Latado, R.R.; Maniero, R.A.; Martins, M.M.; Figueira, A. Citrus carotenoid isomerase gene characterization by complementation of the "Micro-Tom" tangerine mutant. Plant Cell Rep. 2019, 38, 623-636. [CrossRef]

43. Cunningham, F.X.; Pogson, B.; Sun, Z.R.; McDonald, K.A.; DellaPenna, D.; Gantt, E. Functional analysis of the beta and epsilon lycopene cyclase enzymes of Arabidopsis reveals a mechanism for control of cyclic carotenoid formation. Plant Cell 1996, 8 , 1613-1626. [CrossRef]

44. Devitt, L.C.; Fanning, K.; Dietzgen, R.G.; Holton, T.A. Isolation and functional characterization of a lycopene beta-cyclase gene that controls fruit colour of papaya (Carica papaya L.). J. Exp. Bot. 2010, 61, 33-39. [CrossRef] [PubMed]

45. Koc, I.; Filiz, E.; Tombuloglu, H. Comparative analysis of plant lycopene cyclases. Comput. Biol. Chem. 2015, 58, 81-92. [CrossRef] [PubMed]

46. Lu, S.W.; Zhang, Y.; Zheng, X.J.; Zhu, K.J.; Xu, Q.; Deng, X.X. Isolation and functional characterization of a lycopene $\beta$-cyclase gene promoter from citrus. Front. Plant Sci. 2016, 7, 1367. [CrossRef]

47. Zeng, J.; Wang, C.; Chen, X.; Zang, M.L.; Yuan, C.H.; Wang, X.T.; Wang, Q.; Li, M.; Li, X.Y.; Chen, L.; et al. The lycopene $\beta$-cyclase plays a significant role in provitamin A biosynthesis in wheat endosperm. BMC Plant Biol. 2015, 15, 112. [CrossRef]

48. Zhang, J.C.; Zhou, W.J.; Xu, Q.; Tao, N.G.; Ye, J.L.; Guo, F.; Xu, J.; Deng, X.X. Two lycopene $\beta$-cyclases genes from sweet orange (Citrus sinensis L. Osbeck) encode enzymes with different functional efficiency during the conversion of lycopene-to-provitamin A. J. Integr. Agric. 2013, 12, 1731-1747. [CrossRef]

49. Zhao, D.Q.; Zhou, C.H.; Sheng, Y.L.; Liang, G.H.; Tao, J. Molecular cloning and expression of phytoene synthase, lycopene beta-cyclase, and beta-carotene hydroxylase genes in persimmon (Diospyros kaki L.) fruits. Plant Mol. Biol. Rep. 2011, 29, 345-351. [CrossRef]

50. Zhu, H.S.; Chen, M.D.; Wen, Q.F.; Li, Y.P. Isolation and characterization of the carotenoid biosynthetic genes $L C Y B, L C Y E$ and CHXB from strawberry and their relation to carotenoid accumulation. Sci. Hortic. 2015, 182, 134-144. [CrossRef]

51. Gao, Z.; Liu, Q.; Zheng, B.; Chen, Y. Molecular characterization and primary functional analysis of PeVDE, a violaxanthin de-epoxidase gene from bamboo (Phyllostachys edulis). Plant Cell Rep. 2013, 32, 1381-1391. [CrossRef]

52. Li, X.; Zhao, W.; Sun, X.; Huang, H.; Kong, L.; Niu, D.; Sui, X.; Zhang, Z. Molecular cloning and characterization of violaxanthin de-epoxidase (CsVDE) in cucumber. PLoS ONE 2013, 8, e64383. [CrossRef]

53. Jeknić, Z.; Morré, J.T.; Jeknić, S.; Jevremović, S.; Subotić, A.; Chen, T.H. Cloning and functional characterization of a gene for capsanthin-capsorubin synthase from tiger lily (Lilium lancifolium Thunb.'Splendens'). Plant Cell Physiol. 2012, 53, 1899-1912. [CrossRef] 
54. Ahrazem, O.; Rubio-Moraga, A.; Berman, J.; Capell, T.; Christou, P.; Zhu, C.F.; Gomez-Gomez, L. The carotenoid cleavage dioxygenase CCD2 catalysing the synthesis of crocetin in spring crocuses and saffron is a plastidial enzyme. New Phytol. 2016, 209, 650-663. [CrossRef] [PubMed]

55. Huang, F.C.; Molnar, P.; Schwab, W. Cloning and functional characterization of carotenoid cleavage dioxygenase 4 genes. J. Exp. Bot. 2009, 60, 3011-3022. [CrossRef] [PubMed]

56. Rodrigo, M.J.; Alquezar, B.; Alos, E.; Medina, V.; Carmona, L.; Bruno, M.; Al-Babili, S.; Zacarias, L. A novel carotenoid cleavage activity involved in the biosynthesis of citrus fruit-specific apocarotenoid pigments. J. Exp. Bot. 2013, 64, 4461-4478. [CrossRef]

57. Tuan, P.A.; Kim, J.K.; Lee, S.; Chae, S.C.; Park, S.U. Molecular characterization of carotenoid cleavage dioxygenases and the effect of gibberellin, abscisic acid, and sodium chloride on the expression of genes involved in the carotenoid biosynthetic aathway and carotenoid accumulation in the callus of Scutellaria baicalensis Georgi. J. Agric. Food Chem. 2013, 61, 5565-5572.

58. Zheng, X.J.; Xie, Z.Z.; Zhu, K.J.; Xu, Q.; Deng, X.X.; Pan, Z.Y. Isolation and characterization of carotenoid cleavage dioxygenase 4 genes from different citrus species. Mol. Genet. Genom. 2015, 290, 1589-1603. [CrossRef] [PubMed]

59. Tan, B.C.; Joseph, L.M.; Deng, W.T.; Liu, L.J.; Li, Q.B.; Cline, K.; McCarty, D.R. Molecular characterization of the Arabidopsis 9-cis epoxycarotenoid dioxygenase gene family. Plant J. 2003, 35, 44-56. [CrossRef]

60. Sekimoto, H.; Seo, M.; Dohmae, N.; Takio, K.; Kamiya, Y.; Koshiba, T. Cloning and molecular characterization of plant aldehyde oxidase. J. Biol. Chem. 1997, 272, 15280-15285. [CrossRef]

61. Wu, J.; Peng, L.; Dong, S.; Xia, X.; Zhao, L. Transcriptome analysis of Chelidonium majus elaiosomes and seeds provide insights into fatty acid biosynthesis. Peer]. 2019, 7, e6871. [CrossRef]

62. Pourmazaheri, H.; Soorni, A.; Kohnerouz, B.B.; Dehaghi, N.K.; Kalantar, E.; Omidi, M.; Naghavi, M.R. Comparative analysis of the root and leaf transcriptomes in Chelidonium majus L. PLoS ONE 2019, 14, e0215165. [CrossRef]

63. Lopez-Emparan, A.; Quezada-Martinez, D.; Zuniga-Bustos, M.; Cifuentes, V.; Iniguez-Luy, F.; Federico, M.L. Functional analysis of the Brassica napus L. phytoene synthase (PSY) gene family. PLoS ONE 2014, 9, e114878. [CrossRef] [PubMed]

64. Kaur, N.; Pandey, A.; Kumar, P.; Pandey, P.; Kesarwani, A.K.; Mantri, S.S.; Awasthi, P.; Tiwari, S. Regulation of banana phytoene synthase (MaPSY) expression, characterization and their modulation under various abiotic stress conditions. Front. Plant Sci. 2017, 8, 462. [CrossRef] [PubMed]

65. Zhou, X.-T.; Jia, L.-D.; Duan, M.-Z.; Chen, X.; Qiao, C.-L.; Ma, J.-Q.; Zhang, C.; Jing, F.-Y.; Zhang, S.-S.; Yang, B. Genome-wide identification and expression profiling of the carotenoid cleavage dioxygenase (CCD) gene family in Brassica napus L. PLoS ONE 2020, 15, e0238179.

66. Zhe, Q.L.; Zheng, J.L.; Liu, J.H. Transcription activation of beta-carotene biosynthetic genes at the initial stage of stresses as an indicator of the increased $\beta$-carotene accumulation in isolated Dunaliella salina strain GY-H13. Aquat. Toxicol. 2020, 222, 105472. [CrossRef]

67. Han, Y.; Zheng, Q.S.; Wei, Y.P.; Chen, J.; Liu, R.; Wan, H.J. In silico identification and analysis of phytoene synthase genes in plants. Genet. Mol. Res. 2015, 14, 9412-9422. [CrossRef] [PubMed]

68. Cui, H.L.; Wang, Y.C.; Qin, S. Molecular evolution of lycopene cyclases involved in the formation of carotenoids in eukaryotic algae. Plant Mol. Biol. Rep. 2011, 29, 1013-1020. [CrossRef]

69. Zhu, Y.H.; Jiang, J.G.; Chen, Q. Characterization of cDNA of lycopene beta-cyclase responsible for a high level of beta-carotene accumulation in Dunaliella salina. Biochem. Cell Biol. 2008, 86, 285-292. [CrossRef]

70. Zhu, Y.H.; Jiang, J.G.; Yan, Y.; Chen, X.W. Isolation and characterization of phytoene desaturase cDNA involved in the betacarotene biosynthetic pathway in Dunaliella salina. J. Agric. Food Chem. 2005, 53, 5593-5597. [CrossRef]

71. DePristo, M.A.; Weinreich, D.M.; Hartl, D.L. Missense meanderings in sequence space: A biophysical view of protein evolution. Nat. Rev. Genet. 2005, 6, 678-687. [CrossRef] [PubMed]

72. Garg, R.; Jhanwar, S.; Tyagi, A.K.; Jain, M. Genome-wide survey and expression analysis suggest diverse roles of glutaredoxin gene family members during development and response to various stimuli in rice. DNA Res. 2010, 17, 353-367. [CrossRef]

73. Yan, P.; Gao, X.Z.; Shen, W.T.; Zhou, P. Cloning and expression analysis of phytoene desaturase and $\zeta$-carotene desaturase genes in Carica papaya. Mol. Biol. Rep. 2011, 38, 785-791. [CrossRef] [PubMed]

74. Hugueney, P.; Badillo, A.; Chen, H.C.; Klein, A.; Hirschberg, J.; Camara, B.; Kuntz, M. Metabolism of cyclic carotenoids-A model for the alteration of this biosynthetic pathway in Capsicum annuum chromoplasts. Plant J. 1995, 8, 417-424. [CrossRef]

75. Lao, Y.M.; Jin, H.; Zhou, J.; Zhang, H.J.; Cai, Z.H. Functional characterization of a missing branch component in Haematococcus pluvialis for control of algal carotenoid biosynthesis. Front. Plant Sci. 2017, 8, 1341. [CrossRef] [PubMed]

76. Pettersen, E.F.; Goddard, T.D.; Huang, C.C.; Couch, G.S.; Greenblatt, D.M.; Meng, E.C.; Ferrin, T.E. UCSF chimera-A visualization system for exploratory research and analysis. J. Comput. Chem. 2004, 25, 1605-1612. [CrossRef] [PubMed]

77. Bouvier, F.; Keller, Y.; D'Harlingue, A.; Camara, B. Xanthophyll biosynthesis: Molecular and functional characterization of carotenoid hydroxylases from pepper fruits (Capsicum annuum L.). Biochim. Biophys. Acta Lipids Lipid Met. 1998, 1391, 320-328. [CrossRef]

78. Charron, J.-B.F.; Ouellet, F.; Pelletier, M.; Danyluk, J.; Chauve, C.; Sarhan, F. Identification, expression, and evolutionary analyses of plant lipocalins. Plant Physiol. 2005, 139, 2017-2028. [CrossRef]

79. Arnoux, P.; Morosinotto, T.; Saga, G.; Bassi, R.; Pignol, D. A structural basis for the pH-dependent xanthophyll cycle in Arabidopsis thaliana. Plant Cell 2009, 21, 2036-2044. [CrossRef]

80. Bouvier, F.; Camara, B. Molecular analysis of carotenoid cyclase inhibition. Arch. Biochem. Biophys. 1997, 346, 53-64. [CrossRef] 
81. Mialoundama, A.S.; Heintz, D.; Jadid, N.; Nkeng, P.; Rahier, A.; Deli, J.; Camara, B.; Bouvier, F. Characterization of plant carotenoid cyclases as members of the flavoprotein family functioning with no net redox change. Plant Physiol. 2010, 153, 970-979. [CrossRef]

82. Messing, S.A.J.; Gabelli, S.B.; Echeverria, I.; Vogel, J.T.; Guan, J.C.; Tan, B.C.; Klee, H.J.; McCarty, D.R.; Amzel, L.M. Structural insights into maize viviparous14, a key enzyme in the biosynthesis of the phytohormone abscisic acid. Plant Cell 2010, 22, 2970-2980. [CrossRef]

83. Schwartz, S.H.; Tan, B.C.; Gage, D.A.; Zeevaart, J.A.D.; McCarty, D.R. Specific oxidative cleavage of carotenoids by VP14 of maize. Science 1997, 276, 1872-1874. [CrossRef] [PubMed]

84. Zdunek-Zastocka, E. Molecular cloning, characterization and expression analysis of three aldehyde oxidase genes from Pisum sativum L. Plant Physiol. Biochem. 2008, 46, 19-28. [CrossRef]

85. Joyard, J.; Ferro, M.; Masselon, C.; Seigneurin-Berny, D.; Salvi, D.; Garin, J.; Rolland, N. Chloroplast proteomics and the compartmentation of plastidial isoprenoid biosynthetic pathways. Mol. Plant 2009, 2, 1154-1180. [CrossRef] [PubMed]

86. Kang, C.; Zhai, H.; Xue, L.Y.; Zhao, N.; He, S.Z.; Liu, Q.C. A lycopene $\beta$-cyclase gene, IbLCYB2, enhances carotenoid contents and abiotic stress tolerance in transgenic sweetpotato. Plant Sci. 2018, 272, 243-254. [CrossRef] [PubMed]

87. Li, P.R.; Zhang, S.J.; Zhang, S.F.; Li, F.; Zhang, H.; Cheng, F.; Wu, J.; Wang, X.W.; Sun, R.F. Carotenoid biosynthetic genes in Brassica rapa: Comparative genomic analysis, phylogenetic analysis, and expression profiling. BMC Genom. 2015, 16, 492. [CrossRef]

88. Ruiz-Sola, M.A.; Rodriguez-Concepcion, M. Carotenoid biosynthesis in Arabidopsis: A colorful pathway. Arab. Book 2012, 10, e0158. [CrossRef] [PubMed]

89. Cuong, D.M.; Arasu, M.V.; Jeon, J.; Park, Y.J.; Kwon, S.J.; Al-Dhabi, N.A.; Park, S.U. Medically important carotenoids from Momordica charantia and their gene expressions in different organs. Saudi J. Biol. Sci. 2017, 24, 1913-1919. [CrossRef] [PubMed]

90. Tuan, P.A.; Kim, J.K.; Kim, H.H.; Lee, S.Y.; Park, N.I.; Park, S.U. Carotenoid accumulation and characterization of cDNAs encoding phytoene synthase and phytoene desaturase in Garlic (Allium sativum). J. Agric. Food Chem. 2011, 59, 5412-5417. [CrossRef]

91. Tuan, P.A.; Kim, J.K.; Park, N.I.; Lee, S.Y.; Park, S.U. Carotenoid content and expression of phytoene synthase and phytoene desaturase genes in bitter melon (Momordica charantia). Food Chem. 2011, 126, 1686-1692. [CrossRef]

92. Tuan, P.A.; Kim, J.K.; Lee, J.; Park, W.T.; Kwon, D.Y.; Kim, Y.B.; Kim, H.H.; Kim, H.R.; Park, S.U. Analysis of carotenoid accumulation and expression of carotenoid biosynthesis genes in different organs of Chinese cabbage (Brassica rapa Subsp. pekinensis). Exp. Clin. Sci. J. 2012, 11, 508-516.

93. Pillai, S.; Behra, R.; Nestler, H.; Suter, M.J.F.; Sigg, L.; Schirmer, K. Linking toxicity and adaptive responses across the transcriptome, proteome, and phenotype of Chlamydomonas reinhardtii exposed to silver. Proc. Natl. Acad. Sci. USA 2014, 111, 3490-3495. [CrossRef] [PubMed]

94. Schwanhausser, B.; Busse, D.; Li, N.; Dittmar, G.; Schuchhardt, J.; Wolf, J.; Chen, W.; Selbach, M. Global quantification of mammalian gene expression control. Nature 2011, 473, 337-342. [CrossRef]

95. Jin, X.; Bai, C.; Bassie, L.; Nogareda, C.; Romagosa, I.; Twyman, R.M.; Christou, P.; Zhu, C. Zm PBF and Zm GAMYB transcription factors independently transactivate the promoter of the maize (Zea mays) $\beta$-carotene hydroxylase 2 gene. New Phytol. 2019, 222, 793-804. [CrossRef] [PubMed]

96. Koul, A.; Sharma, D.; Kaul, S.; Dhar, M.K. Identification and in silico characterization of cis-acting elements of genes involved in carotenoid biosynthesis in tomato. 3 Biotech 2019, 9, 287. [CrossRef] [PubMed]

97. Zhu, Q.L.; Guo, S.N.; Wen, F.; Zhang, X.L.; Wang, C.C.; Si, L.F.; Zheng, J.L.; Liu, J.H. Transcriptional and physiological responses of Dunaliella salina to cadmium reveals time-dependent turnover of ribosome, photosystem, and ROS-scavenging pathways. Aquat. Toxicol. 2019, 207, 153-162. [CrossRef] [PubMed]

98. Amiour, N.; Imbaud, S.; Clément, G.; Agier, N.; Zivy, M.; Valot, B.; Balliau, T.; Armengaud, P.; Quilleré, I.; Cañas, R. The use of metabolomics integrated with transcriptomic and proteomic studies for identifying key steps involved in the control of nitrogen metabolism in crops such as maize. J. Exp. Bot. 2012, 63, 5017-5033. [CrossRef] [PubMed]

99. Balazadeh, S.; Schildhauer, J.; Araújo, W.L.; Munné-Bosch, S.; Fernie, A.R.; Proost, S.; Humbeck, K.; Mueller-Roeber, B. Reversal of senescence by $\mathrm{N}$ resupply to N-starved Arabidopsis thaliana: Transcriptomic and metabolomic consequences. J. Exp. Bot. 2014, 65, 3975-3992. [CrossRef] [PubMed]

100. Larsen, P.E.; Sreedasyam, A.; Trivedi, G.; Desai, S.; Dai, Y.; Cseke, L.J.; Collart, F.R. Multi-Omics approach identifies molecular mechanisms of plant-fungus mycorrhizal interaction. Front. Plant Sci. 2016, 6, 1061. [CrossRef]

101. Maruyama, K.; Urano, K.; Yoshiwara, K.; Morishita, Y.; Sakurai, N.; Suzuki, H.; Kojima, M.; Sakakibara, H.; Shibata, D.; Saito, K. Integrated analysis of the effects of cold and dehydration on rice metabolites, phytohormones, and gene transcripts. Plant Physiol. 2014, 164, 1759-1771. [CrossRef]

102. Zhu, Q.; Zeng, D.; Yu, S.; Cui, C.; Li, J.; Li, H.; Chen, J.; Zhang, R.; Zhao, X.; Chen, L. From golden rice to aSTARice: Bioengineering astaxanthin biosynthesis in rice endosperm. Mol. Plant 2018, 11, 1440-1448. [CrossRef]

103. Shumskaya, M.; Wurtzel, E.T. The carotenoid biosynthetic pathway: Thinking in all dimensions. Plant Sci. 2013, 208, 58-63. [CrossRef]

104. Mistry, J.; Chuguransky, S.; Williams, L.; Qureshi, M.; Salazar, G.A.; Sonnhammer, E.L.; Tosatto, S.C.; Paladin, L.; Raj, S.; Richardson, L.J. Pfam: The protein families database in 2021. Nucleic Acids Res. 2021, 49, D412-D419. [CrossRef]

105. Lu, S.; Wang, J.; Chitsaz, F.; Derbyshire, M.K.; Geer, R.C.; Gonzales, N.R.; Gwadz, M.; Hurwitz, D.I.; Marchler, G.H.; Song, J.S. CDD/SPARCLE: The conserved domain database in 2020. Nucleic Acids Res. 2020, 48, D265-D268. [CrossRef] 
106. Geourjon, C.; Deleage, G. SOPMA: Significant improvements in protein secondary structure prediction by consensus prediction from multiple alignments. Bioinformatics 1995, 11, 681-684. [CrossRef]

107. Petersen, T.N.; Brunak, S.; Von Heijne, G.; Nielsen, H. SignalP 4.0: Discriminating signal peptides from transmembrane regions. Nat. Methods 2011, 8, 785-786. [CrossRef] [PubMed]

108. Yu, C.S.; Chen, Y.C.; Lu, C.H.; Hwang, J.K. Prediction of protein subcellular localization. Proteins 2006, 64, 643-651. [CrossRef] [PubMed]

109. Emanuelsson, O.; Nielsen, H.; Heijne, G.V. ChloroP, a neural network-based method for predicting chloroplast transit peptides and their cleavage sites. Protein Sci. 1999, 8, 978-984. [CrossRef]

110. Emanuelsson, O.; Nielsen, H.; Brunak, S.; Von Heijne, G. Predicting subcellular localization of proteins based on their N-terminal amino acid sequence. J. Mol. Biol. 2000, 300, 1005-1016. [CrossRef]

111. Horton, P.; Park, K.-J.; Obayashi, T.; Fujita, N.; Harada, H.; Adams-Collier, C.; Nakai, K. WoLF PSORT: Protein localization predictor. Nucleic Acids Res. 2007, 35, W585-W587. [CrossRef]

112. Gasteiger, E.; Gattiker, A.; Hoogland, C.; Ivanyi, I.; Appel, R.D.; Bairoch, A. ExPASy: The proteomics server for in-depth protein knowledge and analysis. Nucleic Acids Res. 2003, 31, 3784-3788. [CrossRef] [PubMed]

113. Hall, T.A. BioEdit: A user-friendly biological sequence alignment editor and analysis program for Windows 95/98/NT. Nucleic Acids Symp. 1999, 41, 95-98.

114. Kelley, L.A.; Mezulis, S.; Yates, C.M.; Wass, M.N.; Sternberg, M.J.E. The Phyre2 web portal for protein modeling, prediction and analysis. Nat. Protoc. 2015, 10, 845-858. [CrossRef]

115. Bailey, T.L.; Boden, M.; Buske, F.A.; Frith, M.; Grant, C.E.; Clementi, L.; Ren, J.Y.; Li, W.W.; Noble, W.S. MEME SUITE: Tools for motif discovery and searching. Nucleic Acids Res. 2009, 37, W202-W208. [CrossRef]

116. Kumar, S.; Stecher, G.; Tamura, K. MEGA7: Molecular evolutionary genetics analysis version 7.0 for bigger datasets. Mol. Biol. Evol. 2016, 33, 1870-1874. [CrossRef] [PubMed]

117. Saitou, N.; Nei, M. The neighbor-joining method-A new method for reconstructing phylogenetic trees. Mol. Biol. Evol. 1987, 4, 406-425.

118. Felsenstein, J. Confidence limits on phylogenies: An approach using the bootstrap. Evolution 1985, 39, 783-791. [CrossRef]

119. Sievers, F.; Wilm, A.; Dineen, D.; Gibson, T.J.; Karplus, K.; Li, W.; Lopez, R.; McWilliam, H.; Remmert, M.; Söding, J. Fast, scalable generation of high-quality protein multiple sequence alignments using Clustal Omega. Mol. Syst. Biol. 2011, 7, 539. [CrossRef]

120. Madeira, F.; Park, Y.M.; Lee, J.; Buso, N.; Gur, T.; Madhusoodanan, N.; Basutkar, P.; Tivey, A.R.N.; Potter, S.C.; Finn, R.D.; et al. The EMBL-EBI search and sequence analysis tools APIs in 2019. Nucleic Acids Res. 2019, 47, W636-W641. [CrossRef]

121. Silver, N.; Best, S.; Jiang, J.; Thein, S.L. Selection of housekeeping genes for gene expression studies in human reticulocytes using real-time PCR. BMC Mol. Biol. 2006, 7, 33. [CrossRef]

122. Park, C.H.; Xu, H.; Yeo, H.J.; Park, Y.E.; Hwang, G.-S.; Park, N.I.; Park, S.U. Enhancement of the flavone contents of Scutellaria baicalensis hairy roots via metabolic engineering using maize Lc and Arabidopsis PAP1 transcription factors. Metab. Eng. 2021, 64, 64-73. [CrossRef]

123. Babicki, S.; Arndt, D.; Marcu, A.; Liang, Y.; Grant, J.R.; Maciejewski, A.; Wishart, D.S. Heatmapper: Web-enabled heat mapping for all. Nucleic Acids Res. 2016, 44, W147-W153. [CrossRef]

124. Park, C.H.; Yeo, H.J.; Park, S.Y.; Kim, J.K.; Park, S.U. Comparative phytochemical analyses and metabolic profiling of different phenotypes of Chinese cabbage (Brassica rapa ssp. pekinensis). Foods 2019, 8, 587. [CrossRef] 